Full metadata for this item is available in Research@StAndrews:FullText at:

http://research-repository.st-andrews.ac.uk/

\title{
Interest rate rules and welfare in open economies
}

Ozge Senay

\begin{tabular}{|l|l|}
\hline Date of deposit & 09/02/2012 \\
\hline Version & This is an author version of this work. \\
\hline Access rights & $\begin{array}{l}\text { C This item is protected by original copyright. } \\
\text { This work is made available online in accordance with publisher } \\
\text { policies. To see the final definitive version of this paper please } \\
\text { visit the publisher's website. }\end{array}$ \\
\hline $\begin{array}{l}\text { Citation for } \\
\text { published version }\end{array}$ & $\begin{array}{l}\text { Senay, O. (2008). Interest rate rules and welfare in open } \\
\text { economies. Scottish Journal of Political Economy, 55(3): pp300- } \\
\text { 329. }\end{array}$ \\
\hline $\begin{array}{l}\text { Link to published } \\
\text { version }\end{array}$ & http://dx.doi.org/10.1111/j.1467-9485.2008.00455.x \\
\hline
\end{tabular}




\title{
Interest Rate Rules and Welfare in Open Economies
}

\author{
Ozge Senay* \\ Scool of Economics and Finance \\ University of St Andrews ${ }^{\dagger}$
}

October 1, 2007

\begin{abstract}
This paper analyses the welfare performance of a set of five alternative interest rate rules in an open economy stochastic dynamic general equilibrium model with nominal rigidities. A rule with a lagged interest rate term, high feedback on inflation and low feedback on output is found to yield the highest welfare for a small open economy. This result is robust across different degrees of openness, different sources of home and foreign shocks, alternative foreign monetary rules and different specifications for price setting behaviour. The same rule emerges as both the Nash and cooperative equilibria in a two-country version of the model.
\end{abstract}

Keywords: Welfare, Monetary Policy, Interest Rate Rules, Second Order Approximation

JEL: E52, E58, F41

\footnotetext{
${ }^{*}$ I am grateful for useful comments and suggestions from an anonymous referee and the editors.

${ }^{\dagger}$ Scool of Economics and Finance, University of St Andrews, St Andrews, KY16 9AL. Tel:+44 1334 462422, Fax:+44 1334 462444, E-mail: os12@st-andrews.ac.uk
} 


\section{Introduction}

Recent research on monetary policy has focused on the use of interest rate rules in which the nominal interest rate is adjusted in response to economic conditions. A rule proposed by Taylor (1993) to act as a guide for policymakers setting short-run interest rates has especially attracted widespread interest. "Taylor rules" in general specify that the shortrun interest rate should be altered in response to an increase in inflation and/or a fall in real output below targeted levels. ${ }^{1}$ The collection of papers in Taylor (1999a) provide a sample of the different variations on the benchmark Taylor rule analysed in many papers. Indeed, in his introduction to this volume, Taylor (1999a) suggests that the set of rules used by different authors in the volume is "representative of the degree of disagreement" among researchers. Taylor (1999a) is regarded as a central reference within the literature on monetary policy rules.

In common with much research on monetary policy rules, the papers in the Taylor (1999a) volume are mostly focused on closed economy models. ${ }^{2}$ However, open economy issues such as the behaviour of exchange rates and the importance of the exchange rate as a key transmission mechanism of monetary policy, especially in transmitting the effects of external shocks, are central to monetary policy. Thus, it is essential to extend the closed economy literature on monetary rules to an open economy framework.

The objective of this paper is to extend the closed economy analysis of monetary policy rules, as exemplified by the papers of the Taylor volume, to a general open economy setting. A sticky-price general equilibrium model of an open economy is used to evaluate the relative welfare performance of the set of interest rate rules examined in the nine different papers in the Taylor (1999a) volume. The model used draws on the open economy models

\footnotetext{
${ }^{1}$ See Clarida, Gali and Gertler (1999), Taylor(1999a) and the June 1999 special issue of the Journal of Monetary Economics.

${ }^{2}$ Only two of the nine papers in the Taylor volume consider open economy models (Ball (1999) and Batini and Haldane (1999)). In both these papers the models used are linear structures which do not incorporate explicit microeconomic foundations nor do they consider welfare in terms of the utility of a representative agent.
} 
of Obstfeld and Rogoff $(1995,1998)$ and the closed economy models of Rotemberg and Woodford $(1997,1999){ }^{3}$ This framework is useful for formulating an explicit welfare evaluation of each policy rule using the utility function of the representative agent. Nominal rigidities are introduced in the form of Calvo (1983) price contracts which prevent agents from changing prices in every period in response to domestic and foreign disturbances. The model incorporates home bias in consumption, thereby allowing a comparison of rules under different degrees of economic openness. The home country is subject to stochastic shocks from internal and external sources and the focus of interest is on the stabilisation and welfare implications of the policy rule choice for the home country.

The welfare performance of the different rules is measured using aggregate utility of home agents. In this respect, the paper builds directly on the closed economy analysis of Rotemberg and Woodford (1997 and 1999, which is one of the Taylor (1999a) papers). This paper makes use of the solution technique developed by Sutherland (2002) to calculate aggregate utility for the comparison of the performance of each of the interest-rate rules. The explicit evaluation enabled by the utility-based welfare measure will enable a rigorous comparison of the welfare performances of different rules.

Before proceeding, it is useful to discuss the relationship between the model used in this paper and the models used in the recent open economy literature. The use of microfounded general equilibrium models and utility based welfare measures have, of course, become more standard in recent years. However, within an open economy context many of the recent contributions are only able to obtain results in heavily constrained special cases. ${ }^{4}$ The results emphasised in this recent literature cannot therefore be regarded as

\footnotetext{
${ }^{3}$ King and Wolman (1999), McCallum and Nelson (1999) and Rotemberg and Woodford (1999) are the main papers in the Taylor (1999a) volume which motivate this study. These models are all closed economy, optimising, dynamic stochastic general equilibrium models with representative agents having rational expectations. They also incorporate some form of nominal rigidity in their analyses, through staggered wage or price setting, which imply some trade-off in inflation and output in the short run.

${ }^{4}$ This is because the analysis of aggregate utility within an open economy model is technically much more difficult than in a closed economy model. In fact, the second-order approximation techniques that are required for a fully general analysis have only recently been developed. Such techniques have been
} 
definitive. This is true for instance for the papers by Obstfeld and Rogoff (2002), Clarida, Gali and Gertler (2002), Gali and Monacelli (2005), Devereux and Engel (2003), Corsetti and Pesenti (2004) and Benigno and Benigno (2003). All these authors examine cases where key parameter values, such as the intra- and intertemporal elasticities of substitution, are restricted to specific values. While these authors are able to obtain interesting and clear-cut results relating to the welfare effects of monetary policy, it is important to note that these results are only valid for specific parameter combinations. The results are not valid for more general parameter combinations. By using second-order approximation techniques the analysis in this paper considers the general case with unrestricted parameter values. This implies that intuitions based on results of the papers cited above cannot be applied directly to the model of this paper. Thus, for instance, the optimality of price stabilisation which is emphasised by a number of the above authors, depends crucially on the parameter restrictions imposed in their models. It does not follow that price stabilisation is optimal in the model of this paper. ${ }^{5}$

There are some recent papers analysing Taylor rules using models which are not subject to the above described parameter restrictions. Bergin, Shin and Tchakarov (2005) and developed by Sutherland (2002), and also by Sims (2000) and Schmitt-Grohe and Uribe (2004). It is important to note that, while Woodford (2003) and Rotemberg and Woodford (1999) also use secondorder approximations to analyse welfare, the techniques they use are only appropriate for closed economy settings (or heavily restricted open economy settings). It is only the recently developed second-order techniques (which are used in this paper) that are more generally applicable.

\footnotetext{
${ }^{5}$ Sutherland (2006), who analyses the general case in a static open economy model, has shown that price stabilisation is only optimal in the special cases analysed in many of the above mentioned papers. Other recent contributions in the closed and open economy literature have also questioned the optimality of price stabilisation. For instance, again using second-order approximation techniques, Benigno and Woodford (2004) have shown that price stabilisation is not optimal when there are shocks to government spending. Benigno (2001) and Devereux (2004) have shown that price stabilisation is not optimal when international financial markets are incomplete. Sutherland's (2004) results show that price stabilisation is not a Nash equilibrium of non-coordinated monetary policy in a two-country world (except in the cases of special parameter combinations analysed by the above authors).
} 
Kollmann (2002) have made use of second-order approximation techniques to investigate the welfare effects of monetary policy rules. But these authors do not analyse the set of rules considered in the Taylor (1999a) volume and they restrict attention to simple Taylor rules without terms in the lagged interest rate. The results of this paper show that rules including the lagged interest rate can perform significantly better in welfare terms. Batini, Haldane and Millard (2003) also analyse Taylor rules in a general model but their measure of welfare does not make use of a full second-order approximation. ${ }^{6}$

The paper initially focuses on a model which is widely accepted as a benchmark in the recent open economy macroeconomics literature (see for instance Benigno and Benigno (2003), Clarida, Gali and Gertler (2002), Gali and Monacelli (2005), Kirsanova, Leith and Wren-Lewis (2006)). ${ }^{7}$ At its most basic level the model incorporates sticky prices in the form of Calvo (1983) contracts where prices are set in the currency of the producer. Closed economy models of this general type have been subject to quite extensive estimation and empirical testing (see for instance Rotemberg and Woodford (1997), Smets and Wouters (2004, 2005a, 2005b), Juillard, Karan, Laxton and Pesenti (2005) and Rabanal and Rubio-Ramirez (2005). There has also been empirical testing and estimations of open economy versions of the general model, these include Bergin (2003, 2004). Bergin's general conclusion is that the framework is a reasonably good fit for both small open and large open economies. There is however evidence that the model fits better when goods prices are set in the local currency of the buyer rather than that of the producer. The closed economy literature also finds a better fit of these models when the model includes some element of backward price-setting. This paper considers extensions of the

\footnotetext{
${ }^{6}$ Batini, Haldane and Millard (2003) omit the first-order terms from the second-order welfare expression, but recent literature shows these terms to be important for an appropriate valuation of welfare.

${ }^{7}$ The general structure of the model is also compatible with New Keynesian models of the type for example described by Svensson (2000). Svensson describes his model in terms of an open economy IS curve and a New Keynesian Phillips curve. The model described in this paper may be reduced to similar relationships. It is important to note that while Svensson (2000) uses an ad hoc measure of welfare, the current analysis uses a utility-based welfare measure.
} 
benchmark framework which in turn incorporates both these features.

The results of the benchmark model reported below show that a rule, with a lagged interest rate term, high feedback on inflation and low feedback on output delivers the highest welfare for a small open economy. ${ }^{8}$ This result is robust across different degrees of openness, different sources of home and foreign shocks and for alternative foreign monetary rules. The same rule also emerges as both the Nash and cooperative equilibria in a twocountry version of the model. The results of the benchmark model are also found to carry over to a variant of the model with backward-looking price setting and to an alternative variant of the model where prices are set in the currency of the buyer.

The paper proceeds as follows: Section 2 specifies the types of monetary rules to be compared, section 3 presents the structure of the model, section 4 discusses the solution method and the welfare measure, section 5 presents a numerical analysis of the welfare performances and volatilities of alternative policy rules for different degrees of openness, for different foreign monetary policies, for different sources of shocks and for different parameter values in a small country case. Section 6 considers two different price-setting specifications, section 7 analyses the two equal-sized countries case, section 8 analyses a set of open economy rules with exchange rate terms and section 9 concludes.

\section{The Taylor Volume Interest Rate Rules}

The monetary policy rules analysed in this paper are listed in Table 1 . These rules are taken from the Taylor (1999a) volume, where different authors test the robustness of these rules to different model and parameter specifications. Obviously, the rules in Table 1 do not encompass all possible policy rules. However, they do provide a sample of the different variations on the benchmark Taylor rule analysed in many papers. All the rules have the

\footnotetext{
${ }^{8}$ The superior welfare performance of a rule with a high feedback on inflation and a low feedback on output is consistent with the results of Bergin, Shin and Tchakarov (2005) and Kollmann (2002). These authors, however, do not consider rules with a lagged interest rate term.
} 
following general form:

$$
\hat{\imath}_{t}=g_{Y} \hat{Y}_{t}+g_{\pi} \hat{\pi}_{t}+g_{i} \hat{\imath}_{t-1}
$$

where $\hat{\imath}_{t}$ represents the deviation of the nominal interest rate from its steady state level, $\hat{Y}_{t}$ represents the log-deviation of output from its steady state level, $\hat{\pi}_{t}$ represents the log-deviation of the consumer price inflation rate from its steady state level and $\hat{\imath}_{t-1}$ represents the deviation of the lagged nominal interest rate from its steady state level. Each parameter $g_{j}$ measures the extent to which the interest rate responds to deviations of the variable $j$ from its steady state value.

\begin{tabular}{|c|c|c|c|}
\hline Rules & $g_{Y}$ & $g_{\pi}$ & $g_{i}$ \\
\hline I & 0.8 & 3.0 & 1.0 \\
\hline II & 1.0 & 1.2 & 1.0 \\
\hline III & 0.5 & 1.5 & 0.0 \\
\hline IV & 1.0 & 1.5 & 0.0 \\
\hline $\mathbf{V}$ & 0.06 & 1.22 & 1.3 \\
\hline
\end{tabular}

Table 1: The Five Taylor (1999a) Rules

Rules III and IV are simple Taylor rules where the interest rate responds only to real output and the inflation rate. Rule III is the original Taylor (1993) rule. Rule IV is suggested by Henderson and McKibbin (1993) and supported by Ball (1997) and Williams (1999) who argue that the interest rate should respond more aggressively to changes in output. Rules, I, II and V, generalise the Taylor rule to include the lagged interest rate. These are called "interest rate smoothing" rules since the interest rate responds only gradually to changes in output and inflation and the interest rate is only partially adjusted. Rule II is a simple modification of the Taylor rule with a weight on the lagged interest rate equal to that on output. Rule I has a greater weight on inflation relative to output than rule II. Rule V is proposed by Rotemberg and Woodford (1999) and unlike I and II, places a small weight on output and a relatively high weight on the lagged interest 
rate. They propose this rule following a welfare analysis that finds significant welfare improvements by allowing the interest rate to respond to lagged values of itself. ${ }^{9}$

\section{The Model}

The model is a variation of the sticky-price general equilibrium structure which has, following the approach developed by Obstfeld and Rogoff $(1995,1998)$, been often used in the recent open economy macroeconomics literature. ${ }^{10}$

The model consists of two countries, a small home country and a large foreign country, inhabited by a continuum of infinitely lived individual agents who are consumer/producers. Agents consume a group of differentiated, perishable goods of total measure unity. These goods are indexed by $z$ on the unit interval. Home country agents produce fraction $n$ goods and foreign agents produce $1-n$ goods. ${ }^{11}$ Each individual agent uses labour effort to produce a single good and is the monopoly supplier of that good. Prices are assumed to be sticky in that some agents cannot immediately respond to economic disturbances by changing prices within the period under consideration. Instead, these agents respond to disturbances by meeting market demand at pre-set prices. The specific form of sluggish price adjustment considered here is that described by Calvo (1983), which assumes that agents change their prices after time intervals of random length such that an agent is allowed to change the price of his/her good with probability $(1-\gamma)$.

The world economy is assumed to be disturbed by a range of stochastic shocks including labour supply shocks and government expenditure shocks originating in both countries. The home and foreign monetary authorities are assumed to be following a policy which consists of an interest rate rule of the form described in the previous section. Most of

\footnotetext{
${ }^{9}$ It is important to emphasise that none of the five policy rules is intended to be fully optimal within the model described below. The purpose of the papers in the Taylor (1999a) volume is to investigate the robustness of these five rules across a range of different specifications, as is the objective of this paper.

${ }^{10}$ See Lane (2001) for a survey of this literature.

${ }^{11} n$ will be taken to be small except when considering cooperation between two equal-sized countries, as explained below in Section 7 .
} 
the analysis focuses on the choice of monetary policy rule for the home economy when the home economy is small relative to the foreign economy. The welfare performance of each of the five rules is considered for the home economy under: $i$. different degrees of openness of the home country; ii. for different foreign monetary policies; and iii. for different sources of shocks hitting the home and foreign economies.

The detailed structure of the home country is described below. The foreign country has an identical structure. Where appropriate, foreign real variables and foreign currency prices are denoted with an asterisk.

All agents in the home economy have utility functions of the same form. The utility of agent $h$ is given by

$$
U_{t}(h)=E_{t}\left[\sum_{s=t}^{\infty} \beta^{s-t}\left(\frac{C_{s}^{1-\rho}(h)}{1-\rho}+\chi \log \frac{M_{s}(h)}{P_{s}}-\frac{K_{s}}{\mu} y_{s}^{\mu}(h)\right)\right]
$$

where $\chi$ is a positive constant, $C$ is a consumption index defined across all home and foreign goods, $M$ denotes end-of-period nominal money holdings, $P$ is the consumer price index, $y(h)$ is the output of good $h$ and $E$ is the expectations operator. $K$ is a stochastic shock to labour supply preferences which evolves as follows

$$
\log K_{t}=\zeta_{K} \log K_{t-1}+\varepsilon_{K, t}
$$

where $\varepsilon_{K}$ is symmetrically distributed over the interval $[-\epsilon, \epsilon]$ with $E\left[\varepsilon_{K}\right]=0$ and $\operatorname{Var}\left[\varepsilon_{K}\right]=\sigma_{K}^{2}$. An increase in $K$ represents an increase in the marginal disutility of labour and implies a fall in labour supply.

The consumption index $C$ for home agents is defined as

$$
C=\left[[1-(1-n) \nu]^{\frac{1}{\theta}} C_{H}^{\frac{\theta-1}{\theta}}+[(1-n) \nu]^{\frac{1}{\theta}} C_{F}^{\frac{\theta-1}{\theta}}\right]^{\frac{\theta}{\theta-1}}
$$

where $C_{H}$ and $C_{F}$ are indices of home and foreign produced goods defined as follows

$$
C_{H}=\left[\left(\frac{1}{n}\right)^{\frac{1}{\phi}} \int_{0}^{n} c_{H}(i)^{\frac{\phi-1}{\phi}} d i\right]^{\frac{\phi}{\phi-1}}, \quad C_{F}=\left[\left(\frac{1}{1-n}\right)^{\frac{1}{\phi}} \int_{n}^{1} c_{F}(j)^{\frac{\phi-1}{\phi}} d j\right]^{\frac{\phi}{\phi-1}}
$$

where $\phi>1, c_{H}(i)$ is consumption of home good $i$ and $c_{F}(j)$ is consumption of foreign good $j$. The parameter $\theta$ is the elasticity of substitution between home and foreign 
goods. The parameter $\nu$ is a measure of openness, $\nu=0$ is equivalent to a completely closed economy and $\nu=1$ to a completely open economy. An alternative interpretation for this parameter is that it determines the degree of home bias. Given that one of the purposes of the current paper is to evaluate the relative performances of the five rules in an open economy model, as opposed to the closed economy models of the Taylor (1999a) volume, using a measure of openness will enable a comparison of the closed $(\nu=0)$ and the open $(\nu=1)$ economy versions of this model with the closed economy models in Taylor (1999a).

The aggregate consumer price index for home agents is

$$
P=\left[[1-(1-n) \nu] P_{H}^{1-\theta}+[(1-n) \nu] P_{F}^{1-\theta}\right]^{\frac{1}{1-\theta}}
$$

where $P_{H}$ and $P_{F}$ are the price indices for home and foreign goods respectively defined as

$$
P_{H}=\left[\frac{1}{n} \int_{0}^{n} p_{H}(i)^{1-\phi} d i\right]^{\frac{1}{1-\phi}}, \quad P_{F}=\left[\frac{1}{1-n} \int_{n}^{1} p_{F}(j)^{1-\phi} d j\right]^{\frac{1}{1-\phi}}
$$

The law of one price is assumed to hold. This implies $p_{H}(i)=S p_{H}^{*}(i)$ and $p_{F}(j)=$ $S p_{F}^{*}(j)$ for all $i$ and $j$ where an asterisk indicates a price measured in foreign currency and $S$ is the exchange rate (defined as the domestic price of foreign currency). However, note that purchasing power parity does not hold in terms of aggregate consumer price indices, due to the presence of home bias.

It is assumed that international financial trade is restricted to a risk free bond denominated in the currency of the foreign country. ${ }^{12}$ Agent $h$ 's budget constraint is

$$
\begin{aligned}
B_{t}(h) / S_{t}+M_{t}(h)= & \left(1+i_{t-1}^{*}\right) \varphi_{t} B_{t-1}(h) / S_{t}+M_{t-1}(h)+p_{H, t}(h) y_{t}(h) \\
& -P_{t} C_{t}(h)-T_{t}+R_{t}(h)
\end{aligned}
$$

\footnotetext{
${ }^{12}$ In much of the recent open economy literature it is standard to assume that international financial markets allow complete consumption risking. However, the modelling of a complete markets structure is problematic in an asymmetric world (such as a small open economy of the type considered here). Any asymmetry implies an asymmetry in the prices of state-contingent assets. Thus, a full analysis of a complete markets structure requires explicit modelling of asset prices. This complication can be avoided, and thus the model can be considerably simplified, by assuming that international financial trade is restricted to non-contingent bonds.
} 
where $B(h)$ is bond holdings, $M(h)$ is money holdings and $T$ is a lump-sum government transfer.

As is standard in much of the literature, individual agents are assumed to have access to a market for state-contingent assets which allows them to insure against the idiosyncratic income shocks implied by the Calvo pricing structure. ${ }^{13}$ The pay-off to agent $h$ 's portfolio of state-contingent assets is given by $R(h)$.

In order to remove the unit root which arises when international financial trade is restricted to non-contingent bonds, bond holdings are subject to a cost which is related to the aggregate stock of bonds held. The holding cost is represented by the multiplicative term $\varphi_{t}$ in the budget constraint, where

$$
\varphi_{t}=1 /\left(1+\delta B_{t-1}\right)
$$

and $B$ is the aggregate holding of bonds by the home population.

Home agents can also hold wealth in the form of a home nominal bond which is not internationally traded but which can be a substitute for the foreign bond amongst home agents. The rate of return on the home nominal bond will be linked to the rate of return on the foreign bond by the generalised uncovered interest rate parity relationship as follows

$$
\left(1+i_{t}\right)=\left(1+i_{t}^{*}\right) \varphi_{t} \frac{1}{S_{t}} \frac{E\left[\frac{S_{t+1} C_{t+1}^{-\rho}}{P_{t+1}}\right]}{E\left[\frac{C_{t+1}^{-\rho}}{P_{t+1}}\right]}
$$

The home country's government purchases a basket of home goods of per capita amount $G_{t}$, prints money and makes lump sum transfers, $T_{t}$. The government budget constraint is

$$
M_{t}-M_{t-1}+T_{t}-P_{H} G_{t}=0
$$

Changes in the money supply are assumed to enter and leave the economy via changes in lump-sum transfers.

\footnotetext{
${ }^{13}$ There is a separate market for state-contingent assets in each country and there is no international trade in state-contingent assets.
} 
Government purchases are subject to stochastic shocks such that $G$ evolves as follows

$$
\log G_{t}=\zeta_{G} \log G_{t-1}+\varepsilon_{G, t}
$$

where $\varepsilon_{G}$ is symmetrically distributed over the interval $[-\epsilon, \epsilon]$ with $E\left[\varepsilon_{G}\right]=0$ and $\operatorname{Var}\left[\varepsilon_{G}\right]=\sigma_{G}^{2}$. An increase in $G$ will mean an increase in government purchases of the home country and will be treated as a positive real demand shock.

The intertemporal dimension of home agents' consumption choices gives rise to the familiar consumption Euler equation

$$
C_{t}^{-\rho}=\beta\left(1+i_{t}\right) P_{t} E_{t}\left[\frac{C_{t+1}^{-\rho}}{P_{t+1}}\right]
$$

A similar condition holds for foreign agents.

Individual home demands for representative home good, $h$, and foreign good, $f$, are

$$
c_{H}(h)=C_{H}\left(\frac{p_{H}(h)}{P_{H}}\right)^{-\phi}, c_{F}(f)=C_{F}\left(\frac{p_{F}(f)}{P_{F}}\right)^{-\phi}
$$

where

$$
C_{H}=[1-(1-n) \nu] C\left(\frac{P_{H}}{P}\right)^{-\theta}, C_{F}=[(1-n) \nu] C\left(\frac{P_{F}}{P}\right)^{-\theta}
$$

Foreign demands for home and foreign goods have an identical structure to the home demands. Individual foreign demand for representative home good, $h$, and foreign good, $f$, are given by

$$
c_{H}^{*}(h)=C_{H}^{*}\left(\frac{p_{H}^{*}(h)}{P_{H}^{*}}\right)^{-\phi}, c_{F}^{*}(f)=C_{F}^{*}\left(\frac{p_{F}^{*}(f)}{P_{F}^{*}}\right)^{-\phi}
$$

where

$$
C_{H}^{*}=n \nu C^{*}\left(\frac{P_{H}^{*}}{P^{*}}\right)^{-\theta}, C_{F}^{*}=(1-n \nu) C^{*}\left(\frac{P_{F}^{*}}{P^{*}}\right)^{-\theta}
$$

The total demand for home goods is $Y=n C_{H}+(1-n) C_{H}^{*}+n G$ and the total demand for foreign goods is $Y^{*}=n C_{F}+(1-n) C_{F}^{*}+(1-n) G^{*} \cdot{ }^{14}$

Prices are assumed to be set in the currency of the producer and to be sticky in that some agents cannot immediately respond to economic disturbances by changing prices

\footnotetext{
${ }^{14}$ In line with Benigno (2001), it is assumed that the government of the home country only makes purchases of home goods and the foreign government's purchases consist only of foreign goods.
} 
within the period under consideration. Instead, these agents respond to disturbances by meeting market demand at pre-set prices. The specific form of sluggish price adjustment considered here is that described by Calvo (1983), which assumes that agents change their prices after time intervals of random length. In other words, the specific time period between price changes is a random variable. The probability that a given agent changes its price in any particular period is taken to be a constant, $(1-\gamma)$. Accordingly the probability that a given agent will leave his/her price at the previous pre-determined level is $\gamma$. Given the law of large numbers, the proportion of agents leaving their price levels unchanged is $\gamma$, and the proportion $(1-\gamma)$ reset their prices at a new optimal level. All agents who set their price at time $t$ choose the same price, denoted $p_{H, t}$ for the home country. The first-order condition for the choice of prices implies the following

$$
E_{t}\left\{\sum_{s=t}^{\infty}(\beta \gamma)^{s-t}\left[(\phi-1) \frac{p_{H, t} y_{t, s}}{C_{s}^{\rho} P_{s}}-\phi K_{s} y_{t, s}^{\mu}\right]\right\}=0
$$

where $y_{t, s}=(1 / n) Y_{s}\left(p_{H, t} / P_{H, s}\right)^{-\phi}$ is the period-s output of a home agent whose price was last set in period $t$. It is possible to rewrite the expression for aggregate home producer prices as follows

$$
P_{H, t}=\left[\sum_{s=0}^{\infty}(1-\gamma) \gamma^{s} p_{H, t-s}^{1-\phi}\right]^{\frac{1}{1-\phi}}
$$

As described above, individual agents are assumed to have access to insurance markets which allow them to insure against the idiosyncratic income shocks implied by the Calvo pricing structure. In section 6, two alternative variants of the model are considered, one with backward-looking price setting and the other with local currency pricing.

The foreign economy, except for the fact that it is a large economy (given $n$ is small), has an identical structure to the home economy. The foreign country is assumed to be subject to stochastic shocks to its labour supply such that $K_{t}^{*}$ evolves as follows

$$
\log K_{t}^{*}=\zeta_{K^{*}} \log K_{t-1}^{*}+\varepsilon_{K^{*}, t}
$$

where $\varepsilon_{K^{*}}$ is symmetrically distributed over the interval $[-\epsilon, \epsilon]$ with $E\left[\varepsilon_{K^{*}}\right]=0$ and $\operatorname{Var}\left[\varepsilon_{K^{*}}\right]=\sigma_{K^{*}}^{2}$. Similarly, stochastic shocks to the foreign government's purchases take 
the following form

$$
\log G_{t}^{*}=\zeta_{G^{*}} \log G_{t-1}^{*}+\varepsilon_{G^{*}, t}
$$

where $\varepsilon_{G^{*}}$ is symmetrically distributed over the interval $[-\epsilon, \epsilon]$ with $E\left[\varepsilon_{G^{*}}\right]=0$ and $\operatorname{Var}\left[\varepsilon_{G^{*}}\right]=\sigma_{G^{*}}^{2}$.

The main focus of attention in this paper is on the choice of monetary rule for the small home economy. The objective is to compare the set of interest rules in Table 1. Thus, the model is solved and a measure of welfare is derived for each of the five rules listed in Table 1.

It is also necessary to specify the behaviour of the foreign monetary authority. The foreign monetary authority is assumed to adopt an interest rate rule of the same general form as the home authority, thus

$$
\hat{\imath}_{t}^{*}=g_{Y^{*}} \hat{Y}_{t}^{*}+g_{\pi^{*}} \hat{\pi}_{t}^{*}+g_{i *} \hat{\imath}_{t-1}^{*}
$$

The values of the feedback coefficients in this policy rule will obviously affect the behaviour of foreign country variables and this, in turn, may have implications for the welfare performance of the alternative monetary rules for the home economy. In the analysis below, it is assumed that the foreign country policy rule is restricted to the set of rules in Table 1 and the welfare comparison between home-country policy rules is conducted separately for each of the five possible foreign monetary rules.

\section{Model Solution}

It is not possible to derive an exact solution to the model described above. The model is therefore approximated around a non-stochastic equilibrium (defined as the solution which results when $K=K^{*}=G=G^{*}=1$ and $\left.\sigma_{K}^{2}=\sigma_{K^{*}}^{2}=\sigma_{G}^{2}=\sigma_{G^{*}}^{2}=0\right)$. For any variable $X$ define $\hat{X}=\log (X / \bar{X})$ where $\bar{X}$ is the value of variable $X$ in the non-stochastic equilibrium. $\hat{X}$ is therefore the log-deviation of $X$ from its value in the non-stochastic equilibrium. 
Aggregate (per capita) home welfare in period 0 is defined as

$$
\Omega=\frac{1}{n} E_{0} \sum_{s=0}^{\infty} \beta^{s}\left\{\int_{0}^{n}\left(\frac{C_{s}^{1-\rho}(h)}{1-\rho}-\frac{K_{s}}{\mu} y_{s}^{\mu}(h)\right) d h\right\}
$$

where, for simplicity, the utility of real balances is excluded.

A second-order approximation of $\Omega$ can be written as follows

$$
\begin{aligned}
& (\Omega-\bar{\Omega})=\bar{C}^{1-\rho} E_{0} \sum_{s=0}^{\infty} \beta^{\tau}\left\{\hat{C}_{s}+\frac{1}{2}(1-\rho) \hat{C}_{s}^{2}\right. \\
& \left.-\frac{\phi-1}{\phi}\left[\hat{Y}_{s}+\frac{1}{2} \mu\left(\hat{Y}_{s}+\frac{1}{\mu} \hat{K}_{s}\right)^{2}+\frac{1}{2} \phi(1+\phi(\mu-1)) \Pi_{s}\right]\right\}+O\left(\epsilon^{3}\right)
\end{aligned}
$$

where

$$
\Pi_{s}=\sum_{i=0}^{\infty}(1-\gamma) \gamma^{i}\left(\hat{p}_{H, s-i}-\hat{P}_{H, s}\right)^{2}
$$

where $O\left(\epsilon^{3}\right)$ contains terms of order higher than two in the variables of the model. ${ }^{15}$

Note that the second-order approximation of aggregate utility depends on the first and second moments of consumption, output and prices. In order to analyse aggregate utility, it is necessary to derive second-order accurate solutions for the first moments of the variables of the model. These solutions are obtained numerically using the technique described in Sutherland (2002). The next section reports numerical solutions to the above model (under a variety of specifications) which allow a comparison to be made between the five rules. The numerical solutions are obtained using the following benchmark set of parameter values: The discount factor $\beta=0.99$, the elasticity of substitution for individual goods $\phi=7.66$, the elasticity of substitution between home and foreign goods $\theta=4$ ${ }^{16}$, the work effort preference parameter $\mu=1.47$, the elasticity of intertemporal substi-

\footnotetext{
${ }^{15}$ All log-deviations from the non-stochastic equilibrium are of the same order as the shocks, which (by assumption) are of maximum size $\epsilon$. When presenting an equation which is approximated up to order two it is therefore possible to gather all terms of order higher than two in a single term denoted $O\left(\epsilon^{3}\right)$.

${ }^{16}$ The empirical literature on the elasticity of substitution between home and foreign goods does not provide any clear guidance on an appropriate value for this parameter. Obstfeld and Rogoff (2000), in their brief survey of some of the literature, quote estimates ranging between 1.2 and 21.4 for individual goods. Estimates for the average elasticity across all traded goods lie between 5 and 6 (see Hummels (2001)). The real business cycle literature typically uses a much smaller value for $\theta$, for instance Chari, Kehoe and McGrattan (2002) take $\theta=1.5$.
} 
tution $\rho=1$, bond holding $\operatorname{costs} \delta=0.001$. The values for $\beta, \phi, \mu$ and $\rho$ are taken from Rotemberg and Woodford (1999). The value for $\delta$ (i.e. the parameter determining the costs of bond holdings) is based on the calibration used by Benigno (2001). The parameter $\zeta_{i}$, which determines the persistence of the shocks, is set at 0.95 and $\sigma_{i}=0.007$ for all four sources of shocks $i=K, K^{*}, G, G^{*}$. Productivity shocks are assumed to be correlated across countries with a correlation coefficient of 0.25 . The government spending shocks are similarly correlated. The size of the small open economy $n$, is set at 0.001 .

\section{Comparison of Policy Rules: Small Country Case}

The main objective of this paper is to use the above described open economy model to compare the performance of the set of five Taylor (1999a) rules listed in Table 1. In doing so, several variations of home and foreign monetary policy are analysed. In all the cases considered, the home and foreign monetary authorities are assumed to be following a policy which consists of an interest rate rule of the form described above. The analysis focuses on the choice of monetary policy rule for the home economy when the home economy is small relative to the foreign economy. The welfare performance of each of the five rules is considered for the home economy: $i$. under different degrees of openness of the home country; ii. for different foreign monetary policies ; and iii. for different sources of shocks. Initially, a benchmark case is considered where the set of five rules is compared when the foreign country sets its monetary policy according to the simple Taylor rule, rule III. The effects of different foreign monetary policies are considered in section 5.2. In the benchmark case, there is a mixture of domestic and foreign stochastic labour supply and government expenditure shocks hitting the two countries simultaneously. Section 5.3 repeats the welfare comparison between policy rules in four separate cases where only one of the sources of shocks is present in each case. In Section 5.4. the effects of parameter variations on the above exercises are considered. 


\subsection{Benchmark Results}

Figure 1 shows the welfare values under each of the five rules for all degrees of economic openness, from $\nu=0$, which is equivalent to a completely closed economy to $\nu=1$, which is equivalent to a completely open economy. ${ }^{17}$ Figure 1 shows that the interest rule which delivers the highest welfare for all degrees of openness is rule V, the Rotemberg and Woodford (1999) rule. The next best rule, in terms of welfare, is rule I. Rules II and III, (which produce very similar welfare values) produce lower welfare levels than rules $\mathrm{V}$ and I, and rule IV performs worst of all in terms of welfare. Figure 1 shows that this welfare ranking is unchanging in the degree of openness of the home economy. The welfare performance of each rule does not seem to vary significantly with the degree of openness.

\section{INSERT FIGURE 1 ABOUT HERE}

Note that, when $\nu=0$, the home economy is completely closed, the results may be compared with the results from closed economy models (Rotemberg and Woodford (1999), Taylor (1999a, 1999b)). Figure 1 shows that, in the benchmark case, the welfare ranking of these rules in a closed economy matches the welfare ranking in the open economy. Thus, the differences in the transmission mechanism of monetary policy which arise in the open economy case appear not to affect the welfare ranking of these five rules.

Some of the underlying intuition for the welfare results and other aspects of the performance of these rules may be understood from considering the impact of the different rules on the volatilities of the main macro variables. Table 2 reports the standard deviations (SD) of real output, consumption, the interest rate, the inflation rate and the exchange rate for each policy rule for three different levels of openness of the home economy. The standard deviations of output, the inflation rate and the interest rate are relevant since they indicate how different rules affect the trade-off between output-inflation variability and the trade-off between inflation and interest rate variability.

\section{INSERT TABLE 2 ABOUT HERE}

\footnotetext{
${ }^{17}$ The numerical welfare values reported in Figure 1 and all subsequent tables are measured in units equivalent to the percentage deviation of consumption from the non-stochastic steady state.
} 
First we compare the original Taylor rule, rule III, with rule IV which has a higher feedback coefficient on real output. Table 2 shows that the standard deviation of real output is lower and that of inflation is higher under rule IV than under rule III. This indicates that raising $g_{Y}$ represents a movement along the 'output-inflation trade-off curve'. Figures 2 and 3 plot the variability of output, inflation and the interest rate for all rules, the circles on the figure indicate each rule when the economy is closed $(\nu=0)$, the triangles with the number of the rule followed by the letter $\mathrm{O}$ indicate each rule when the economy is open $(\nu=1)$. Figure 2 is similar to Taylor's policy frontier in the sense that rules that have smaller standard deviations of output tend to have larger standard deviations of inflation and vice versa. Figure 2 shows that moving from rule III to IV, the standard deviation of output falls and the standard deviation of inflation rises.

\section{INSERT FIGURES 2 AND 3 ABOUT HERE}

As evident from Table 2, a higher response coefficient on real output $g_{Y}$, also leads to an increase in the variability of consumption and of the interest rate compared to rule III. There is greater interest rate variability because the higher feedback coefficient on output induces the interest rate to respond more actively to stabilise output. Movements in the variance of consumption is linked to the variance in the interest rate through the consumption Euler equation, (equation (12)). Figure 3 shows that moving from rule III to IV leads to higher variability in both the interest rate and the inflation rate so that rule III dominates rule IV.

Now consider rules I, II and V in Table 2. Rule I has greater feedback on all variables, Rule II has a larger feedback on output relative to inflation and rule V places a very small weight on output relative to inflation. In comparing rule II with rule V, we are analysing the effects of having a higher weight on output relative to inflation and vice versa. Table 2 and Figure 2 show that these rules also imply movements along the 'output-inflation trade-off curve'. A higher feedback from output implies lower output variability attained at the expense of higher volatility in inflation.

Rules I, II and V differ from rules III and IV because they include a lagged interest 
rate term. This implies some degree of interest rate smoothing which in turn, implies that any change in the interest rate has some persistence. Given the forward-looking nature of the model, expectations of a persistent move in the interest rate will imply that any given change in the interest rate has a more powerful effect on variables in the current period. Thus, the interest rate movements needed to achieve a given degree of macroeconomic stabilisation will be smaller when there is a lagged interest rate term in the rule. This explains why the interest rate variance is lower under rule $\mathrm{V}$, for instance, (where the feedback coefficient on the lagged interest rate is the highest of all the rules). Since the variance of consumption follows movements in the variance of the interest rate, this also implies that the variance of consumption is lower under rule $\mathrm{V}$ than the other rules.

This leads to the question of whether there is a trade-off between interest rate volatility and inflation volatility. Taylor (1999b) argues that although the variability of real output and inflation may be reduced by highly aggressive rules, such rules cause the variability of the interest rate to increase considerably. However the results here contradict this conclusion and Figure 3 shows that rules I and V, both highly aggressive rules, give lower interest rate variances than rules III and IV. In fact, rules that do include $i_{t-1}$ lead to lower interest rate variability than equivalent rules that do not. ${ }^{18}$

Notice that the impact of the different rules on the standard deviations reported in Table 2, and the trade-offs discussed above, is relatively unaffected by the degree of openness of the home economy. This can be seen in Figures 2 and 3, when the circles (indicating the standard deviations under each rule when the home economy is closed) are compared with the triangles (indicating the standard deviations under each rule when the home economy is open).

\footnotetext{
${ }^{18}$ This is also in contrast to Taylor's (1999b) finding that the variance of the interest rate is higher in rules which react to $i_{t-1}$. However, Taylor (1999b) recognises that these rules perform poorly and lead to high interest rate variability mostly in models without rational expectations. As explained above, lagged interest-rate rules depend on agents' forward looking behaviour for their success. Given that the model used here includes rational expectations, it is found that all lagged interest rate rules lead to lower interest rate variability than equivalent rules without the lagged interest rate.
} 
The impact of the different rules on the volatilities reported above also help understand the welfare comparison. Aggregate welfare depends negatively on the volatility of inflation and the volatility of consumption. Thus, rules which reduce the volatility of inflation and consumption, such as rules I and V, yield the best welfare outcome. While aggregate welfare also depends on the volatility of output, it is the volatility of output relative to the labour supply shock, $K$, which matters for welfare, not the volatility of output itself. Hence, rules which reduce the volatility of output (such as rules III and IV) result in lower welfare than those rules which stabilise inflation (such as rules I and V).

The analysis of the benchmark model demonstrates the superiority of rule $\mathrm{V}$ compared to the other Taylor volume rules. Subsequent sections will consider a number of important variations of the benchmark model and will show that rule $\mathrm{V}$ continues to outperform the other rules. Before proceeding with that analysis, it is useful to consider rule $\mathrm{V}$ in more detail and investigate the welfare implications of small variations in the coefficients of rule $\mathrm{V}$ in the benchmark model. Figures 4,5 and 6 plot the welfare levels when each of the feedback coefficients $g_{Y}, g_{\pi}$ and $g_{i}$ are varied around their benchmark values, namely $g_{Y}=0.06, g_{\pi}=1.22$ and $g_{i}=1.3$. Figure 4 shows that if the feedback coefficient on output is reduced to approximately zero (while holding $g_{\pi}=1.22$ and $g_{i}=1.3$ ), there is scope for some welfare gain, but this gain is trivial in comparison to the welfare difference between rule $\mathrm{V}$ and the other rules. Figure 5 shows that there is also some scope for increasing welfare by increasing $g_{\pi}$ while holding $\mathrm{g}_{Y}=0.06$ and $\mathrm{g}_{i}=1.3$. Within the values for $g_{\pi}$ plotted, welfare does not reach a maximum, however, it is clear that welfare is very flat and welfare gains are again quite trivial compared to the welfare difference across the five rules. Figure 6 plots welfare $\Omega$ against $g_{i}$, (holding $\mathrm{g}_{Y}=0.06$ and $\mathrm{g}_{\pi}=1.22$ ) and shows that a similar story holds for variations in $g_{i}$. Figures 4,5 and 6 show that the welfare generated by rule $\mathrm{V}$ appears to be close to the maximum that can be achieved with a rule of this form for the benchmark model.

\section{INSERT FIGURES 4, 5 AND 6 ABOUT HERE}

The following sub-sections discuss a number of variations of the benchmark case just 
discussed and show that the welfare ranking is robust across all the variations considered.

\subsection{The Impact of the Foreign Country's Monetary Policy}

The above results have shown that rule V, the Rotemberg and Woodford (1999) rule, leads to the highest welfare level in this open economy model when the foreign country is assumed to be following a monetary policy based on the simple Taylor rule, rule III. The question that is now asked, is how would the performance of the five rules change (if at all), if the large foreign country followed a rule other than rule III? Table 3 presents the welfare values for the home country for the five cases where the foreign country follows in turn each of the five rules. Thus the welfare value given in row $i$, column $j$ in Table 3 is the welfare level for the home economy when the home country follows rule $j$ and the foreign country follows rule $i$. Table 3 panel A gives the welfare results when $\nu=0.5$.and panel $\mathrm{B}$ shows the results with $\nu=1$. Table $3 \mathrm{~A}$ shows that the best policy rule for the home country is always rule $\mathrm{V}$ irrespective of the rule followed by the foreign country. The next best rule is rule I for the home country. The rule leading to the lowest welfare is rule IV. The same pattern can be seen in the case when the home economy is completely open, as shown in Table 3B. Thus, the welfare ranking of rules for the home economy found in the benchmark case appears to be robust across different foreign policy rules.

\section{INSERT TABLE 3 ABOUT HERE}

\subsection{Different Sources of Shocks}

It has long been recognised that the welfare performance of monetary regimes depends on the source of stochastic shocks hitting the economy. In the benchmark case described above, there is a mixture of four different shocks, home and foreign real supply and demand shocks. In order to see whether the welfare ranking identified in the benchmark case is affected by the balance of shocks, the individual effects of each of the stochastic real shocks are now considered separately.

Simulation results presenting the home welfare levels (for different degrees of openness 
of the home economy) when home labour supply shocks are the only source of stochastic shocks hitting the two economies have been obtained. ${ }^{19}$ These results show that, similar to the benchmark case above, rule $\mathrm{V}$ generates the highest welfare, followed by rules I, II, III and IV and that, as in the benchmark case, the degree of openness does not affect the welfare ranking of the rules. The same exercise has been carried out when only stochastic real demand shocks originating from the home country hit the two economies. As with the case with home supply shocks, results show that the comparative welfare ranking of the rules show a similar pattern to the benchmark case. It is again rule $\mathrm{V}$ that yields the highest welfare levels, followed by rules I, II, III and IV following. Again, the degree of openness appears to make little difference to the results obtained. ${ }^{20}$

Simulation results showing the home welfare levels for each of the five rules are also obtained for the case when foreign labour supply shocks are the only source of stochastic shocks hitting the two economies. In the case where the shocks hitting the two economies originate only from the foreign country, it is important to note that the specific monetary policy rule adopted by the foreign country may have implications for the relative performance of the rules adopted by the home country. For this reason, the relative welfare comparison of the five home policy rules is carried out in turn for each of the five possible rules followed by the foreign economy. Welfare results for the case where $\nu=0.5$ show that the rule which delivers the highest home welfare is rule I when the foreign country follows rules II, III and IV. ${ }^{21}$ Results show that when the home economy is completely open $(\nu=1)$, it is rule $\mathrm{V}$ which outperforms the other rules in terms of welfare. The next best rule is I, followed by rules II, III and IV. Thus, in general, the welfare ranking of rules

\footnotetext{
${ }^{19}$ These simulations are carried out assuming that the foreign country's monetary policy is based on following rule III. Note that when the shocks hitting the two countries originate solely from the home economy, the specific foreign monetary policy rule adopted is irrelevant for the relative comparisons of the performance of each of rules adopted by the home country (because in the absence of foreign shocks all variables in the foreign economy do not vary in any case).

${ }^{20}$ These results are not reported but are available upon request.

${ }^{21}$ These are the only cases so far analysed where rule $\mathrm{V}$ is not the best rule. However, in these cases the welfare values of rule $\mathrm{V}$ are only very marginally lower than those of rule I.
} 
for the home economy found in the benchmark case appears to be robust across different foreign policy rules even when the supply shocks hitting the two economies originate only from the foreign economy. This exercise is repeated for the case of foreign demand shocks. Results show that the comparative welfare ranking of the rules show a similar pattern to the benchmark case. It is again rule $\mathrm{V}$ that delivers the highest welfare levels, with rules I, III and II next. ${ }^{22}$ Rule IV again ranks the lowest in terms of home welfare. The degree of openness appears to make little difference to the general pattern of results. ${ }^{23}$

\subsection{Parameter Variations}

Before concluding this section,we briefly consider the extent to which the benchmark results are sensitive to variations in the parameters of the model. Five parameters are likely to be important, namely, $\theta, \rho, \phi, \mu$ and $\zeta_{j}$. The parameter $\theta$, the elasticity of substitution between home and foreign goods is likely to be important because $\theta$ is a main determinant of the strength of the expenditure switching effect and it is known that the expenditure switching effect can play a significant role in the welfare comparison between rules. We consider two alternative values for $\theta, 0.8$ and 6 . The effects of increasing $\rho$, which determines the elasticity of intertemporal substitution, to 6 are considered. The parameter $\phi$ determines the price elasticity of demand for individual goods, (see equations (13) and (15)). The effects of setting $\phi$ to 4 and 12 are considered. The effects of setting $\mu$ to 6 is considered which implies a significantly lower elasticity of labour supply than the benchmark value. Finally, we look at the implications of a higher value for $\zeta_{i}$ which determines the persistence of stochastic shocks. The effects of increasing the degree of persistence of shocks to $\zeta_{i}=0.99$ are analysed. Results varying these five parameters (when there is a mixture of four different shocks, home and foreign real supply and demand shocks, as in the benchmark case) indicate that the benchmark results are robust to all the parameter variations carried out. Rule V continues to deliver the highest welfare

\footnotetext{
${ }^{22}$ For a degree of openness $\nu=0.5$, the ranking of rules II and III switch places, though the difference in welfare levels is quite small.

${ }^{23}$ These results are not reported but are available upon request.
} 
levels under all three degrees of openness of the home economy. ${ }^{24}$

\section{Alternative Pricing Structures}

This section considers two alternative assumptions regarding price-setting and tests the robustness of the welfare ranking of the five rules under each alternative assumption.

\subsection{Backward-Looking Prices}

The Calvo (1983) pricing structure has been subject to criticism because it implies that the inflation rate can adjust very rapidly to shocks. There is in fact extensive empirical evidence suggesting that there is significant inertia in the inflation rate. One way to model sluggish inflation is to allow for some degree of backward-looking behaviour in price setting. It is therefore useful to analyse the robustness of the benchmark welfare results when the benchmark framework is modified to allow some prices to be set in a backward-looking manner. In the benchmark model above, the forward-looking nature of price setting is evident in the first order condition for price setting given in equation (17). In this section, the model is modified by assuming that producers set prices as a weighted average of a forward-looking component, $p_{H, t}^{f}$, and a backward-looking component, $p_{H, t}^{b}$, such that the new price set in period $t$ is

$$
p_{H, t}=\alpha p_{H, t}^{f}+(1-\alpha) p_{H, t}^{b}
$$

where $\alpha$ is the weight given to the forward looking component. The forward looking component is determined from the first-order condition (17) and the backward looking component is determined by the following rule of thumb

$$
p_{H, t}^{b}=P_{H, t-1}+\xi\left(P_{H, t-1}-P_{H, t-2}\right)
$$

where $0<\xi<1$. Thus the backward looking component is determined by the average level of producer prices observed in the previous period, updated by a fraction of the

\footnotetext{
${ }^{24}$ These results are not reported but are available upon request.
} 
observed producer price inflation rate.

Figure 7 shows the welfare values under each of the five rules for different values of $\alpha$, from $\alpha=0$, where producers are entirely backward-looking, to $\alpha=1$, where producers are entirely forward-looking. Figure 7 shows that as $\alpha$ is reduced (i.e. as producers become more backward looking) the welfare performance of the five rules become very similar. Nevertheless, the interest rate rule which delivers the highest welfare is again rule V, except for values of $\alpha<0.1$. Figure 8 shows the welfare values under each of the five rules for different values of $\xi$, where $\xi$ measures the degree of indexation in backward-looking pricing. Figure 8 again shows that rule V yields the highest welfare. ${ }^{25}$

\section{INSERT FIGURES 7 AND 8 ABOUT HERE}

\subsection{Exchange Rate Pass-through}

The benchmark model is based on the assumption that prices are set in the currency of the producer, i.e. producer currency pricing (PCP). However, Bergin (2004) finds strong empirical support for the alternative price setting structure, that of local currency pricing (LCP), where prices are set in the currency of the buyer. PCP implies full pass-through from exchange rate changes to export prices while LCP implies incomplete pass-through.

Given the empirical support for LCP, it is important to consider the impact of incomplete exchange rate pass-through on the welfare performance of the policy rules using the above model. Incomplete exchange rate pass-through is introduced in the model by allowing each producer to set two prices, one for sales to home consumers, and another for sales to foreign consumers. Each price is assumed to be subject to separate Calvo (1983) style price setting processes. Export prices (i.e. prices for homes sales to foreign consumers and foreign sales to home consumers) are assumed to be subject to a fixed degree of indexation to the nominal exchange rate, denoted $\eta$. Thus, $\eta=0$ implies zero pass-through from exchange rate changes to export prices, and $\eta=1$ implies full pass

\footnotetext{
${ }^{25}$ In Figure $7 \xi$ is set equal to 1 and in Figure $8 \alpha$ is set equal to 0.5 . In both figures $\nu=1$, which is equivalent to a completely open economy
} 
through. ${ }^{26}$ Figure 9 shows the welfare values for each of the five rules for different values of $\eta$. These results are based on $\nu=1$. Figure 9 shows that the interest rule which delivers the highest welfare for all degrees of pass-through is again rule $\mathrm{V}$ with the ranking of the rules exactly the same as in the benchmark analysis.

\section{INSERT FIGURE 9 ABOUT HERE}

\section{The Two-Country Case}

The analysis of the choice of the five policy rules now turns to the case where the size of the home and foreign countries are equal, i.e. $n=0.5$. In the small open economy case, by definition, the choice of policy rule for the home economy has no impact on macroeconomic outcomes or welfare in the foreign economy, so the choice of policy rule by the foreign country is independent from the choice of home policy rule. However, when the home economy is large it becomes necessary to analyse jointly the choice of policy rules in both countries. This is best achieved by thinking of the choice of policy rule as being the equilibrium of a policy game. This section will analyse both the coordinated and the non-coordinated choice of policy rules in a game of this type.

\section{INSERT TABLES 4 AND 5 ABOUT HERE}

Table 4 shows the pay-off matrices for the policy game where the pay-offs are the levels of aggregate welfare yielded by combinations of home and foreign policy rules. Table 4 panel A shows the welfare levels for the home economy for the five cases where the foreign country follows each of the five rules and panel B presents the welfare levels for the foreign country for the five cases where the home country follows each of the five rules. (Thus the welfare value given in row $i$, column $j$ in Table $4 \mathrm{~A}$ is the welfare level for the home economy when the home country follows rule $j$ and the foreign country follows rule $i$ and similarly

\footnotetext{
${ }^{26}$ In this analysis it is necessary to set the work effort preference parameter $(\mu)$ equal to unity. This implies utility is linear in work effort. Solving the model for the case where $\mu \neq 1$ is technically extremely difficult in the LCP case. Other authors, using models with LCP, have avoided this problem by assuming utility is additively seperable in labour supply to home and foreign markets.
} 
in Table 4 panel B.) The results in Table $4 \mathrm{~A}$ and B are obtained under the assumption that the degree of openness of the both countries is set at $\nu=0.5$. Table 5 panels $\mathrm{A}$ and B present the results under the assumption that both countries are completely open.

The home welfare levels reported in Table 4A, shows that irrespective of the policy rule followed by the foreign country, the home country obtains the highest welfare by following rule V. For the foreign country, Table 4B shows that rule V again yields the highest welfare irrespective of the policy rule followed by the home country. In the case where the two economies are completely open (shown in Table 5A) it is seen that this pattern is repeated and that rule $\mathrm{V}$ continues to yield higher welfare levels for each country regardless of policy rule followed by the other.

The results presented in Tables 4 and 5 show that, irrespective of the degree of openness, rule $\mathrm{V}$ is a dominant strategy for both countries. Rule $\mathrm{V}$ is therefore both a Nash equilibrium and the coordinated equilibrium in a game over the choice of policy rules. That is, whether the two countries act cooperatively or not, the policy rule which delivers the highest welfare for each country is rule V. As such, these results are in exact accordance with the results of the benchmark case of the small economy analysis. ${ }^{27}$

\section{Open Economy Interest Rate Rules}

The above sections have extended the closed economy analysis of the five Taylor (1999a) rules to an open economy setting and also investigated the robustness of these rules in a variety of different configurations. However, open economy issues such as the behaviour of exchange rates and the importance of the exchange rate as a key transmission mechanism of monetary policy, especially in transmitting the effects foreign shocks, are central to

\footnotetext{
${ }^{27}$ Tables 4 and 5 are based on the case where shocks are the benchmark mixture of home and foreign real supply and real demand disturbances. The pay-off matrices (not reported) which correspond to the four cases where only individual sources of shocks are present show that in all cases rule $\mathrm{V}$ is always a dominant strategy and is thus always both a coordinated and non-coordinated equilibrium choice for both economies.
} 
monetary policy. It is often suggested in policy circles that monetary policy should be used, to some extent, to mitigate fluctuations in the nominal exchange rate. Indeed, there is some empirical evidence that central banks do follow policy rules which include a role for the exchange rate. For instance, Lubik and Schorfheide (2005) and Bergin (2004) find evidence that the Federal Reserve, the Bank of Canada and the Bank of England follow policy rules which include a positive feedback term in the exchange rate. This indicates that policy has been, to some extent, directed towards stabilising the nominal exchange rate for these countries. In the context of this paper, this suggests that it is interesting to analyse the welfare implications of adding an exchange rate term into the interest rate rule. A number of theoretical papers have also considered the role of the exchange rate in policy rules. The conclusions reached in this line of literature are rather mixed. Ball (1999) suggests that including the exchange rate brings a relatively large benefit, while others such as Adolfson (2002), Batini, Harrison and Millard (2003) and Leitemo and Söderstrom (2005) report only minor improvements from including the exchange rate in the rule. Taylor (2001) also concludes that including a direct feedback term on the exchange rate only brings a minor benefit.

\section{INSERT TABLE 6 ABOUT HERE}

One key feature of this existing line of the literature is that it is based on ad hoc measures of welfare rather than the utility-based welfare measure used in this paper. It is therefore valuable to re-examine this issue using the current model. Table 6 shows a number of variants of rule $\mathrm{V}$ which include the rate of change of the nominal exchange rate with coefficients ranging from -0.1 to -0.5 . It is apparent that there is some welfare improvement obtained by including such a term. However, note that the size of the welfare gain is very small and it appears that these welfare gains are possible only if the coefficient on the rate of change of the exchange rate is negative. This implies that stabilising the exchange rate is welfare decreasing rather than welfare increasing.

Another issue which has received some attention in the open economy literature on policy rules is the appropriate definition of inflation to be used in the rule. The benchmark 
analysis is based on using the consumer price index (CPI). Since one of the fundamental welfare costs of inflation volatility in models, such as the one analysed here, is its impact on relative price distortions across producers, it is often argued that monetary policy in an open economy should aim to stabilise producer price inflation. ${ }^{28}$ It is therefore useful to consider an alternative form of rule $\mathrm{V}$ which includes PPI inflation rather than CPI inflation. The welfare results of this rule is shown in the final column of Table 6 . It is apparent that the CPI form of rule V delivers marginally higher welfare than the PPI version, but the welfare difference between the two versions of the rule is minimal.

\section{Conclusions}

This paper uses an open-economy model to compare the relative welfare performances of the set of five interest rate rules of the Taylor (1999) volume. This is done using a stochastic dynamic model which is more general than those that have been widely used in the recent open-economy literature (in the sense that welfare results are obtained for unrestricted parameter values). A rule with a lagged interest rate term, high feedback on inflation and low feedback on output is found to perform well in terms of stabilising inflation and attaining the highest welfare for a small open economy. This result is shown to be robust across different degrees of openness of the home economy, for alternative foreign monetary rules, different sources of home and foreign shocks, a set of key parameter variations and for alternative pricing structures. A two-country version of the model analysing the same set of rules shows that the rule that performs best in the smallcountry analysis also emerges as both the Nash and cooperative equilibria in the twocountry case. While this paper focused on a comparison between a fixed set of policy rules, a brief analysis of more general rules, with open economy elements, was considered. This limited analysis showed that in this framework no significant welfare improvements were to be obtained.

\footnotetext{
${ }^{28}$ See Kirsanova, Leith and Wren-Lewis (2006) for a detailed analysis of this point.
} 


\section{References}

[1] Adolfson, M. (2002) "Incomplete Exchange Rate Pass-through and Simple Monetary Policy Rules" Working Paper No. 136, Sveriges Riksbank.

[2] Ball, L. (1997) "Efficient Rules for Monetary Policy." NBER WP No. 5952.

[3] Ball, L. (1999) "Policy Rules for Open Economies." In J. B. Taylor (ed.) Monetary Policy Rules, University of Chicago Press, Chicago, 127-144.

[4] Batini, N. and Haldane, A. (1999) "Forward-Looking Rules for Monetary Policy" in J. B. Taylor (ed.) Monetary Policy Rules, University of Chicago Press, Chicago,157192.

[5] Batini, N., Harrison, R. and Millard, S. P. (2003) "Monetary Policy Rules for an Open Economy." Journal of Economic Dynamics and Control, 27, 2059-94.

[6] Benigno, P. (2001) "Price Stability with Imperfect Financial Integration." CEPR Discussion Paper No. 2854.

[7] Benigno, G. and Benigno, P. (2003) "Price Stability in Open Economies" Review of Economics Studies, 70, 743-764.

[8] Benigno, P. and Woodford, M. (2004) "Inflation Stabilization and Welfare: The Case of a Distorted Steady State" NBER Working Paper No. 10838

[9] Bergin, P. (2003) "Putting the 'New Open Economy Macroeconomics' to a Test" Journal of International Economics, 60, 3-34.

[10] Bergin, P. (2004) "How Well can the New Open Economy Macroeconomics Explain the Exchange Rate and the Current Account" NBER WP No. 10356

[11] Bergin, P., Shin, H and Tchakarov, I. (2005) "Does Exchange Rate Variability Matter for Welfare? A Quantitative Investigation of Stabilization Policies" University of California at Davis, unpublished manuscript. 
[12] Calvo, G. A. (1983) "Staggered Prices in a Utility-Maximising Framework." Journal of Monetary Economics, 12, 383-98.

[13] Chari, V. V. , Kehoe, P. J. and McGrattan, E. R. (2002) "Can Sticky Price Models Generate Volatile and Persistent Real Exchange Rates?" Review of Economic Studies, $69,533-64$.

[14] Clarida, R., Gali, J. and Gertler, M. (1999) "The Science of Monetary Policy: A New Keynesian Perspective." Journal of Economic Literature 37, 1661-1707.

[15] Clarida, R., Gali J. and Gertler, M. (2002) "A Simple Framework for International Monetary Policy Analysis" Journal of Monetary Economics, 49, 879-904.

[16] Corsetti, G. and Pesenti, P. (2004) "International Dimensions of Optimal Monetary Policy." Journal of Monetary Economics, 52, 281-305.

[17] Devereux, M. B. (2004) "Should the Exchange Rate be a Shock Absorber?" Journal of International Economics, 62, 359-378.

[18] Devereux, M. B. and Engel, C. (2003) "Monetary Policy in an Open Economy Revisited: Price Setting and Exchange Rate Flexibility" Review of Economic Studies, $70,765-783$.

[19] Gali, J. and Monacelli, T. (2005) "Monetary Policy and Exchange Rate Volatility in a Small Open Economy" Review of Economics Studies, 72,

[20] Henderson, D. and McKibbin, W. (1993), "An Assessment of Some Basic Monetary Policy Regime Pairs.” in R. Bryant (ed.) Evaluating Policy Regimes: New Research in Macroeconomics, Brookings Press, Washington.

[21] Hummels, D. (2001) "Towards a Geography of Trade Costs." Purdue University, unpublished manuscript.

[22] Juillard, M., Karam, P,. Laxton, D. and Pesento, P. (2005) "Welfare-Based Monetary Policy Rules in an Estimated DSGE Model of the US Economy " ECB WP No. 613. 
[23] King, R. G. and Wolman, A. L. (1999) "What Should the Monetary Authority do When Prices are Sticky?" in J. B. Taylor (ed.) Monetary Policy Rules, University of Chicago Press, Chicago, 349-98.

[24] Kirsanova, T., Leith, C. and Wren-Lewis, S. (2006) "Should Central Banks Target Consumer Prices or the Exchange Rate?" Economic Journal, 116, F208-F231.

[25] Kollmann, R. (2002) "Monetary Policy Rules in the Open Economy: Effects on Welfare and Business Cycles." Journal of Monetary Economics, 49, 989-1015.

[26] Lane, P. (2001) "The New Open Economy Macroeconomics: A Survey." Journal of International Economics, 54, 235-66.

[27] Leitemo, K. and Söderstrom, U. (2005) "Simple Monetary Policy Rules and Exchange Rate Uncertainty" Journal of International Money and Finance, 24, 481-507.

[28] Lubik, T. A. and Schorfheide, F. (2005) "Do Central Banks Respond to Exchange Rate Movements? A Structural Investigation" Journal of Monetary Economics, forthcoming.

[29] McCallum, B. and Nelson, E. (1999) "Performance of Operational Policy Rules in an Estimated Semi-classical Structural Model.” in J. B. Taylor (ed.) Monetary Policy Rules, University of Chicago Press, Chicago, 15-45.

[30] Obstfeld, M. and Rogoff, K. (1995) "Exchange Rate Dynamics Redux." Journal of Political Economy, 103, 624-60.

[31] Obstfeld, M. and Rogoff, K. (1998) "Risk and Exchange Rates." NBER Working Paper No. 6694.

[32] Obstfeld, M. and Rogoff, K. (2000) "The Six Major Puzzles in International Macroeconomics: Is There a Common Cause?" NBER Macroeconomics Annual, 15, 339-90.

[33] Obstfeld, M. and Rogoff, K. (2002) "Global Implications of Self-Oriented National Monetary Rules" Quarterly Journal of Economics, 117, 503-536. 
[34] Rabanal, P. and Rubio-Ramirez, J. F.(2005) "Comparing new Keynesian Models of the Business Cycle: A Bayesian Approach" Journal of Monetary Economics, 52, $1151-1166$.

[35] Rotemberg, J. J. and Woodford, M. (1997) "An Optimization-Based Econometric Framework for the Evaluation of Monetary Policy." in B. S. Bernanke and J. J. Rotemberg (eds.) NBER Macroeconomics Annual 1997, MIT Press, Cambridge, 297346.

[36] Rotemberg, J. J. and Woodford, M. (1999) "Interest Rate Rules in Estimated Sticky Price Models" in J. B. Taylor (ed.) Monetary Policy Rules, University of Chicago Press, Chicago, 57-119.

[37] Schmitt-Grohe, S. and Uribe, M. (2004) "Solving Dynamic General Equilibrium Models using a Second-order Approximation to the Policy Function." Journal of Economic Dynamics and Control, 28, 755-75.

[38] Sims, C. (2000) "Second-order Accurate Solution of Discrete Time Dynamic Equilibrium Models." Working Paper, Princeton University.

[39] Smets, F. and Wouters, R. (2004) "Forecasting with a Bayesian DSGE Model: An Application to the Euro Area" Journal of the Common Market Studies, 42, 841-867.

[40] Smets, F. and Wouters, R. (2005a) "Bayesian New Neoclassical Synthesis (NNS) Models: Modern Tools for Central Banks" Journal of the European Economic Association, $3,422-433$.

[41] Smets, F. and Wouters, R. (2005b) "Comparing Shocks and Frictions in US and Euro Area Business Cycles: A Bayesian DSGE Approach" Journal of Applied Econometrics, 20, 161-183.

[42] Sutherland, A. (2002) "A Simple Second-Order Solution Method for Dynamic General Equilibrium Models" CEPR Discussion Paper No. 3554. 
[43] Sutherland, A. (2004) "International Monetary Policy Coordination and Financial Market Integration" CEPR Discussion Paper No 4251.

[44] Sutherland, A. (2006) "The Expenditure Switching Effect, Welfare and Monetary Policy in a Small Open Economy." Journal of Economic Dynamics and Control.30, 1159-1182.

[45] Svensson, L. E. O. (2000) "Open Economy Inflation Targeting" Journal of International Economics, 50, 155-183.

[46] Taylor, J. B. (1993) "Discretion versus Policy Rules in Practice." Carnegie-Rochester Conference Series on Public Policy 39, 195-214.

[47] Taylor, J. B. (ed.) (1999a) Monetary Policy Rules, University of Chicago Press, Chicago.

[48] Taylor, J. B. (1999b) "The Robustness and Efficiency of Monetary Policy Rules as Guidelines for Interest Rate Setting by the European Central Bank." Journal of Monetary Economics 43, 655-79.

[49] Taylor, J. B. (2001) "The Role of the Exchange Rate in Monetary Policy Rules" American Economic Review 91, 263-267.

[50] Williams, J. C. (1999) "Simple Rules for Monetary Policy." Working Paper, Federal Reserve Board.

[51] Woodford, M. (2003) Interest and Prices: Foundations of a Theory of Monetary Policy, Princeton University Press, Princeton. 
Figure 1 Impact of Openness

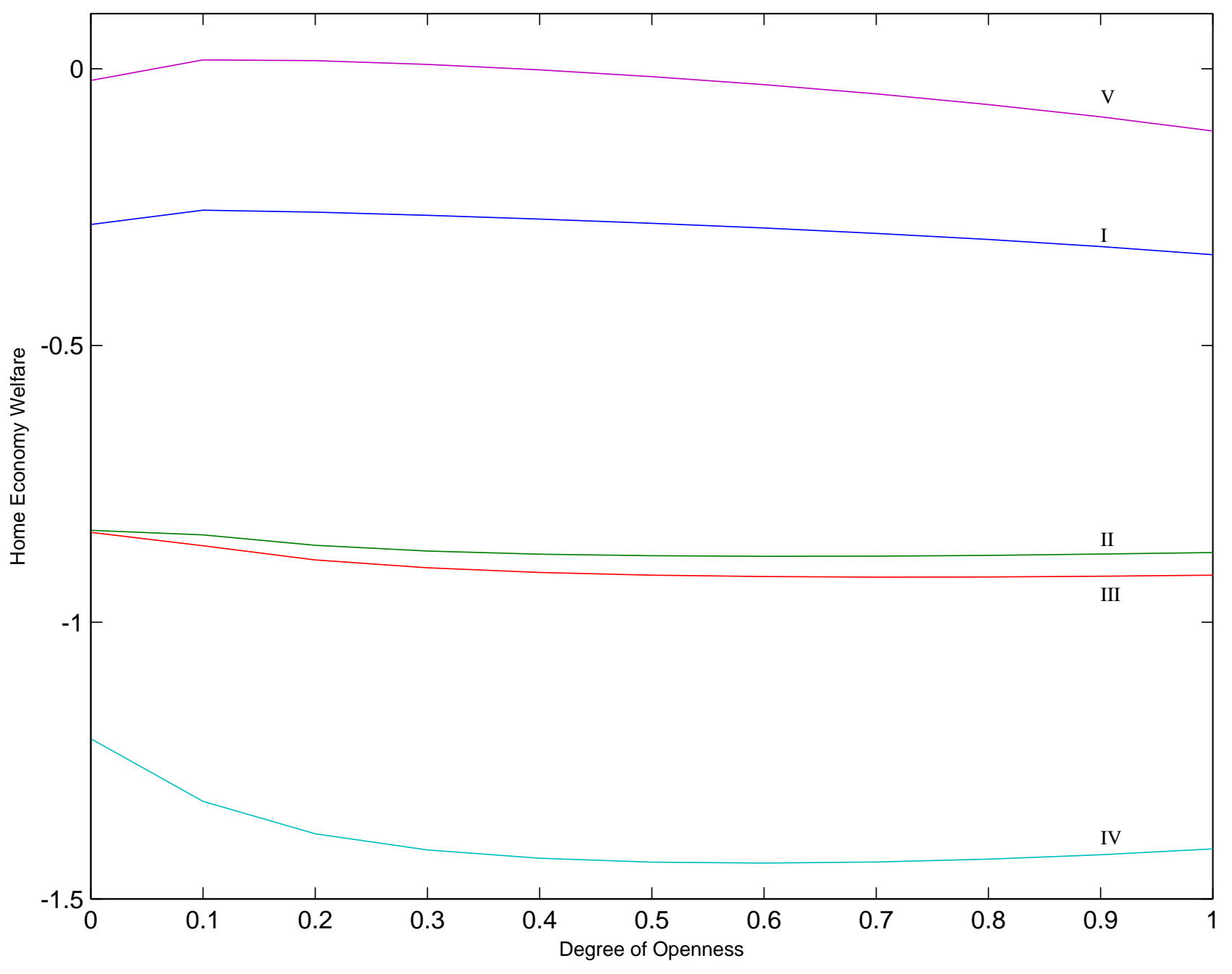


Table 2

Benchmark Standard Deviations of Home Macro Variables

(Foreign Country follows Rule III)

\begin{tabular}{|c|c|c|c|c|c|}
\hline$v=0.0$ & $\mathrm{Y}$ & $\mathrm{C}$ & $\mathrm{i}$ & $\pi$ & $\mathrm{S}$ \\
\hline $\mathrm{I}$ & 0.0134 & 0.0160 & 0.0032 & 0.0036 & 1.1928 \\
\hline $\mathrm{II}$ & 0.0074 & 0.0179 & 0.0054 & 0.0063 & 1.4370 \\
\hline $\mathrm{III}$ & 0.0078 & 0.0169 & 0.0058 & 0.0064 & 1.4428 \\
\hline $\mathrm{IV}$ & 0.0048 & 0.0188 & 0.0069 & 0.0077 & 1.6224 \\
\hline $\mathrm{V}$ & 0.0191 & 0.0159 & 0.0009 & 0.0008 & 1.1395 \\
\hline
\end{tabular}

\begin{tabular}{|c|c|c|c|c|c|}
\hline$v=0.5$ & $\mathrm{Y}$ & $\mathrm{C}$ & $\mathrm{i}$ & $\pi$ & $\mathrm{S}$ \\
\hline $\mathrm{I}$ & 0.0139 & 0.0139 & 0.0034 & 0.0038 & 1.2638 \\
\hline $\mathrm{II}$ & 0.0079 & 0.0151 & 0.0061 & 0.0067 & 1.6863 \\
\hline $\mathrm{III}$ & 0.0080 & 0.0148 & 0.0064 & 0.0069 & 1.7398 \\
\hline $\mathrm{IV}$ & 0.0050 & 0.0160 & 0.0080 & 0.0086 & 2.1064 \\
\hline $\mathrm{V}$ & 0.0201 & 0.0139 & 0.0009 & 0.0009 & 1.1499 \\
\hline
\end{tabular}

\begin{tabular}{|c|c|c|c|c|c|}
\hline$v=1.0$ & $\mathrm{Y}$ & $\mathrm{C}$ & $\mathrm{i}$ & $\pi$ & $\mathrm{S}$ \\
\hline $\mathrm{I}$ & 0.01400 & 0.01376 & 0.00344 & 0.00380 & 1.26590 \\
\hline $\mathrm{II}$ & 0.00797 & 0.01468 & 0.00616 & 0.00687 & 1.68420 \\
\hline $\mathrm{III}$ & 0.00830 & 0.01437 & 0.00650 & 0.00698 & 1.74460 \\
\hline $\mathrm{IV}$ & 0.00526 & 0.01528 & 0.00813 & 0.00879 & 2.09950 \\
\hline $\mathrm{V}$ & 0.02009 & 0.01367 & 0.00090 & 0.00094 & 1.14950 \\
\hline
\end{tabular}


Figure 2. Standard Deviations of Output and Inflation

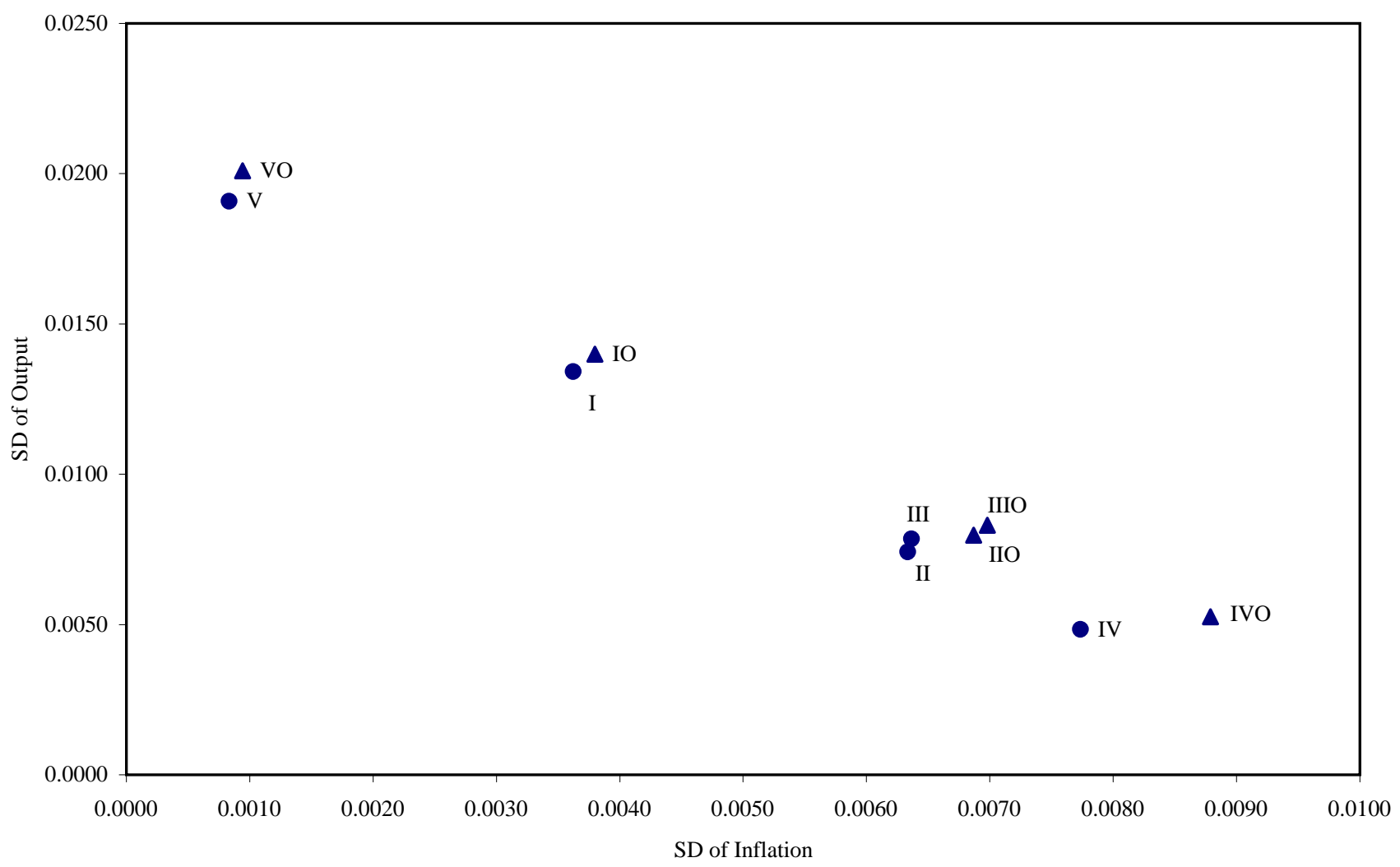

Figure 3. Standard Deviations of Interest Rate and Inflation

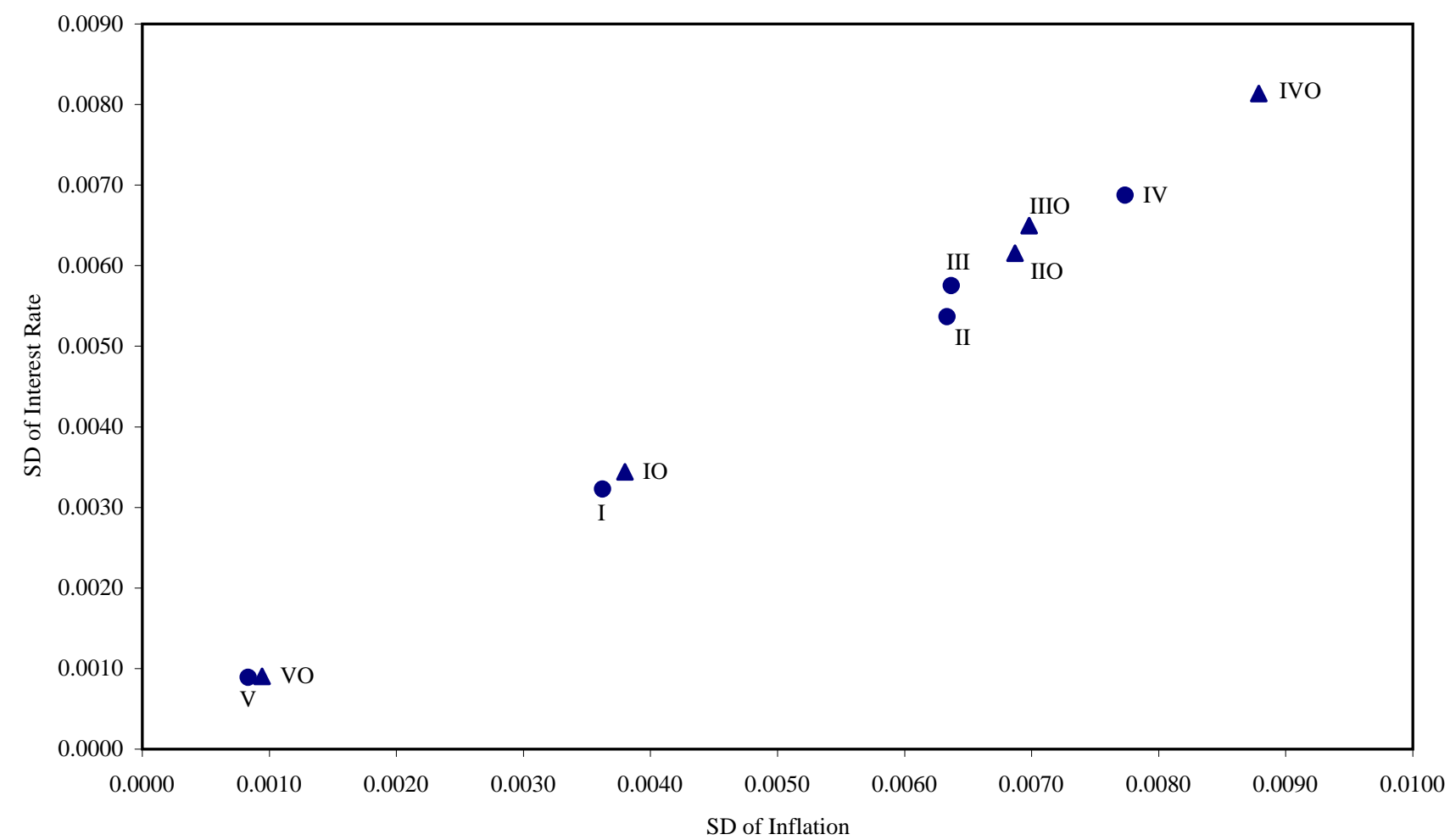


Figure 4 Varying the feedback coefficient on output

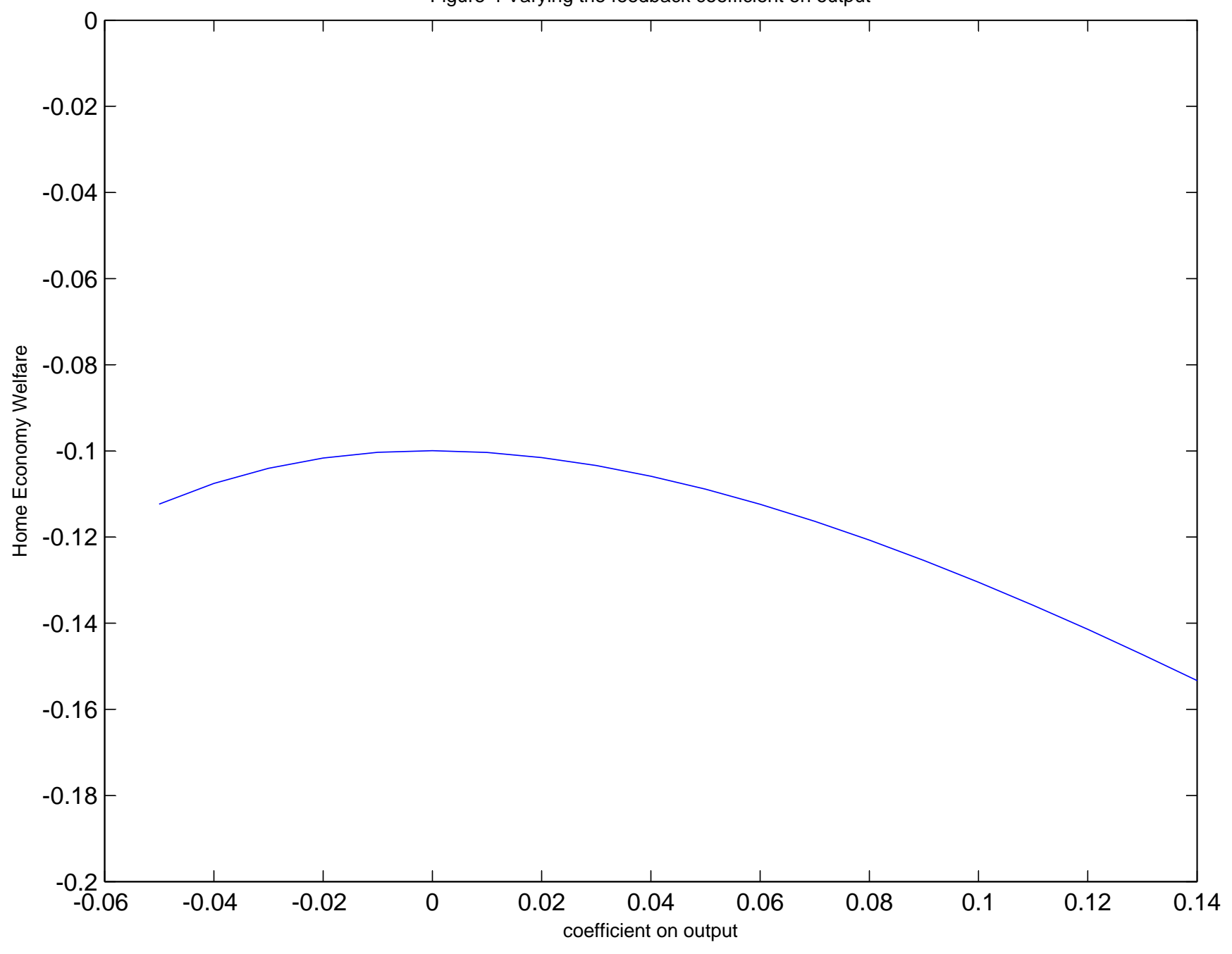


Figure 5 Varying the feedback coefficient on inflation

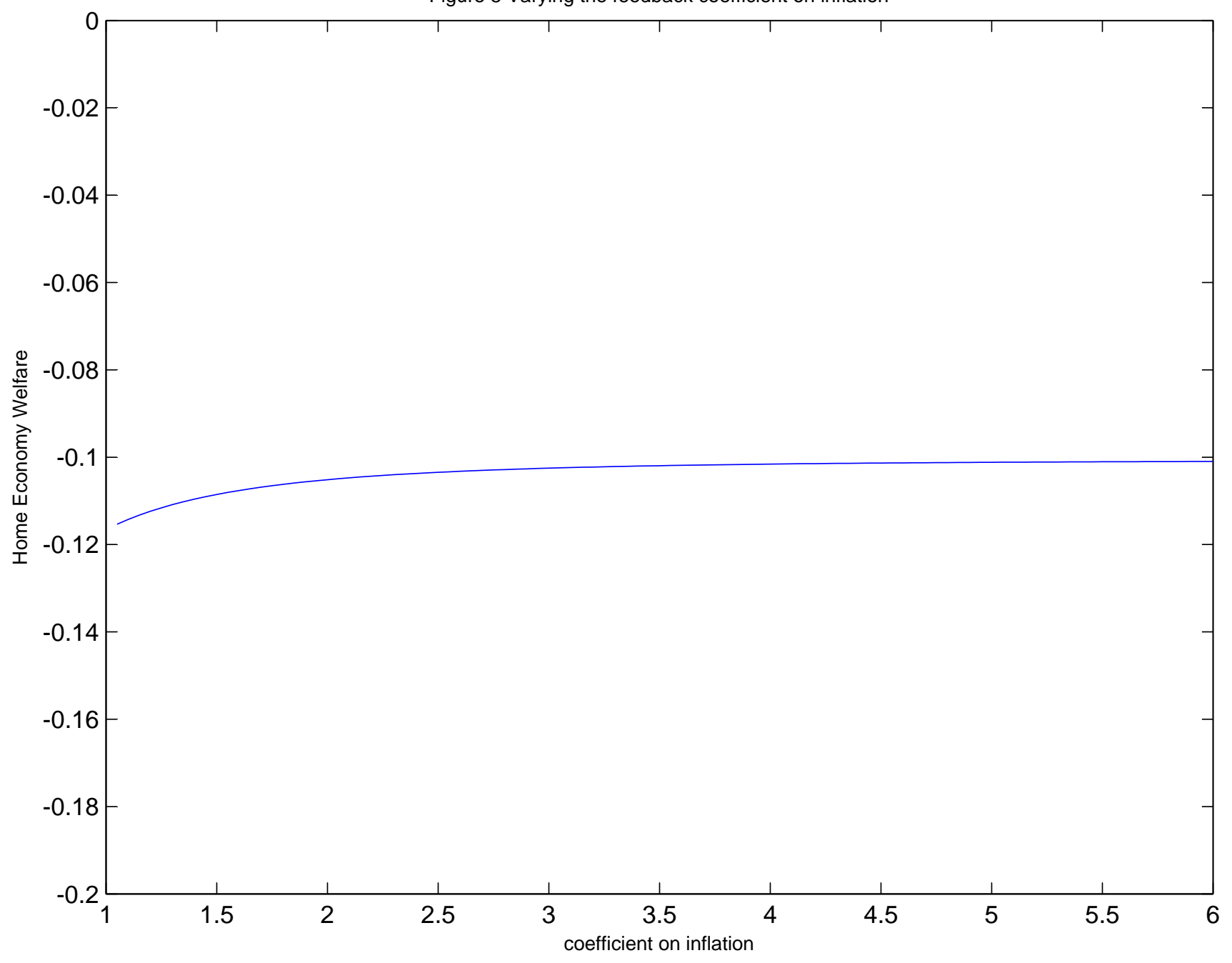


Figure 6 Varying the feedback coefficient on the lagged interest rate

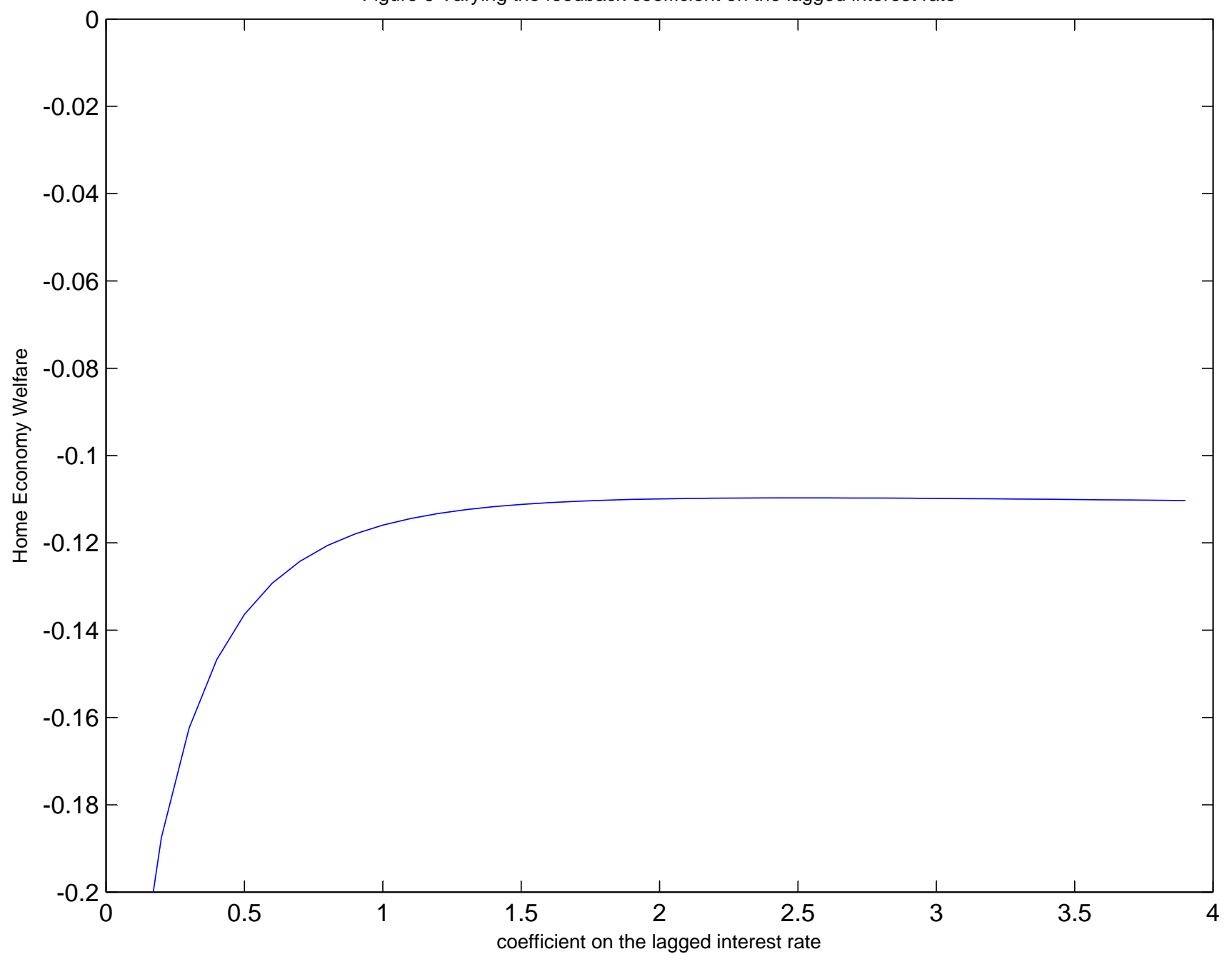


Table 3 Impact of Foreign Country Monetary Policy on Home Welfare

Table 3A

$v=0.5$

Home Welfare

Home Rule

\begin{tabular}{|c|c|c|c|c|c|}
\cline { 2 - 6 } \multicolumn{1}{c|}{} & I & II & III & IV & V \\
\hline Foreign Rule & & & & & \\
\hline I & -0.2872 & -0.8867 & -0.9289 & -1.4544 & -0.0307 \\
\hline II & -0.2725 & -0.8738 & -0.9045 & -1.4260 & -0.0086 \\
\hline III & -0.2791 & -0.8799 & -0.9150 & -1.4335 & -0.0142 \\
\hline IV & -0.2497 & -0.8550 & -0.8859 & -1.4061 & 0.0210 \\
\hline V & -0.2755 & -0.8779 & -0.9287 & -1.4651 & -0.0247 \\
\hline
\end{tabular}

Table 3B

$v=1.0$

Home Welfare

Home Rule

\begin{tabular}{|c|c|c|c|c|c|}
\cline { 2 - 6 } \multicolumn{1}{c|}{} & I & II & III & IV & V \\
\hline Foreign Rule & & & & & \\
\hline I & -0.2876 & -0.8250 & -0.8723 & -1.3734 & -0.0696 \\
\hline II & -0.3328 & -0.8712 & -0.9075 & -1.4052 & -0.1115 \\
\hline III & -0.3358 & -0.8740 & -0.9150 & -1.4097 & -0.1124 \\
\hline IV & -0.3237 & -0.8656 & -0.9032 & -1.3995 & -0.0976 \\
\hline V & -0.2418 & -0.7820 & -0.8379 & -1.3489 & -0.0279 \\
\hline
\end{tabular}


Figure 7 Impact of Backward Looking Prices

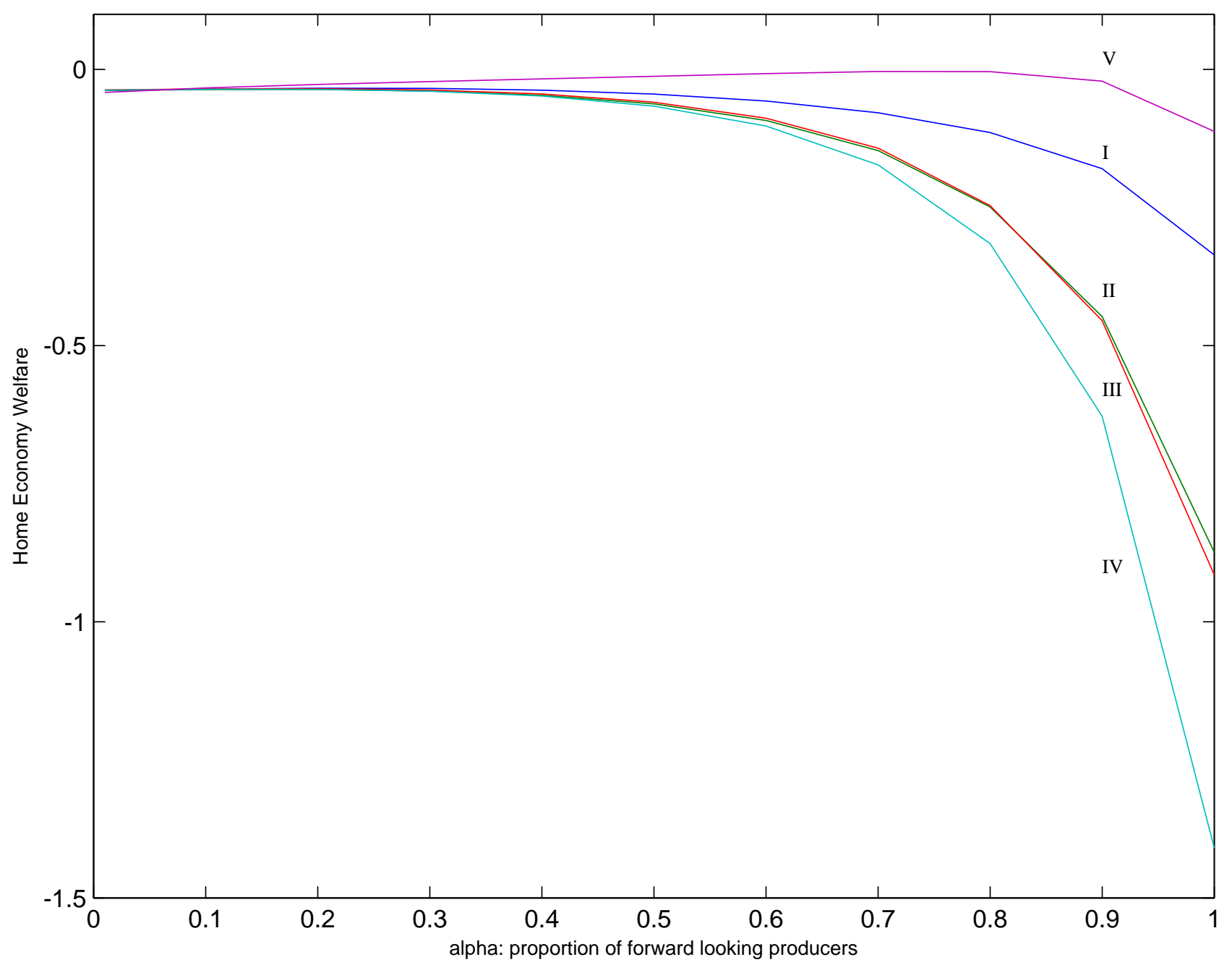




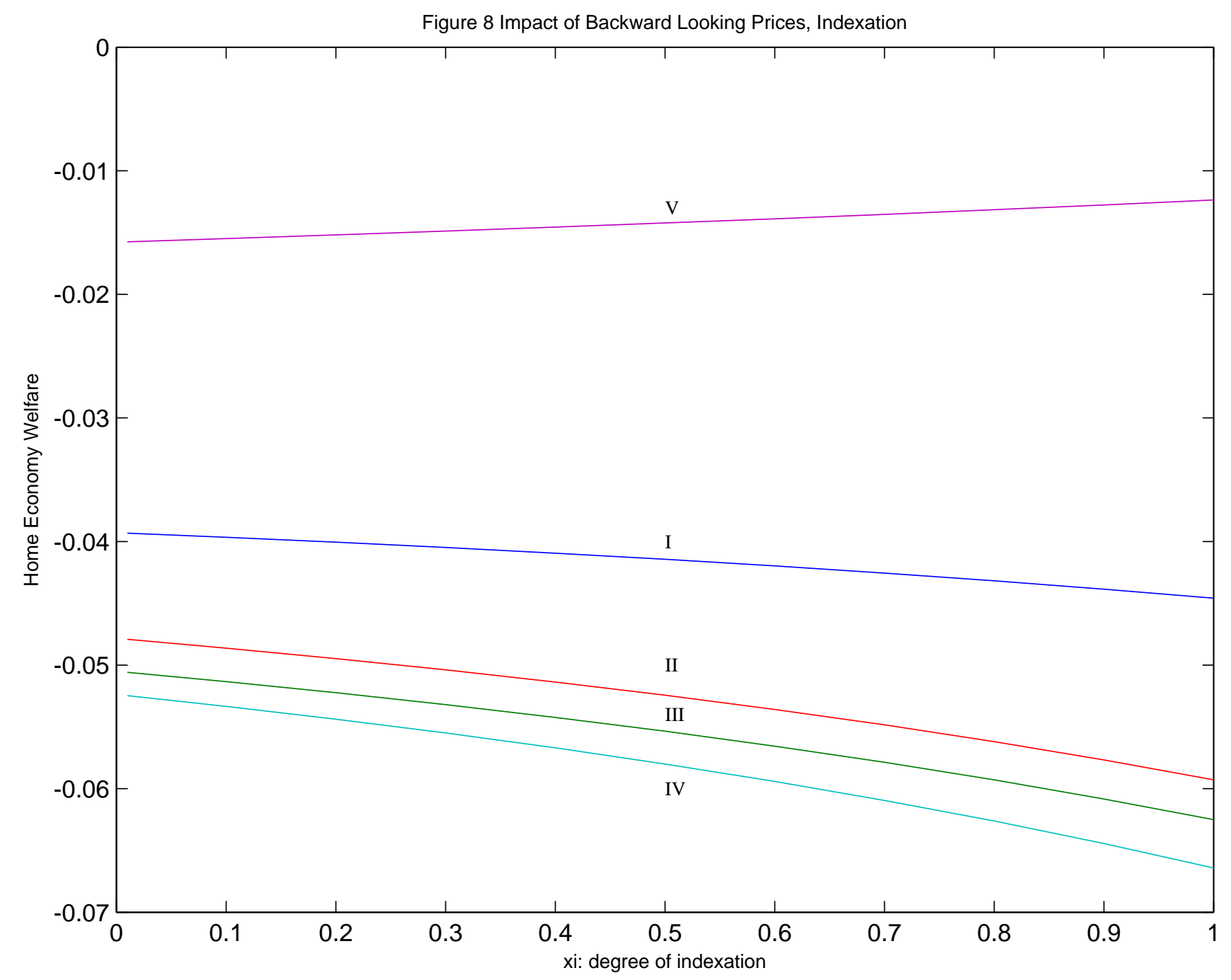


Figure 9 Impact of Incomplete Pass-Through

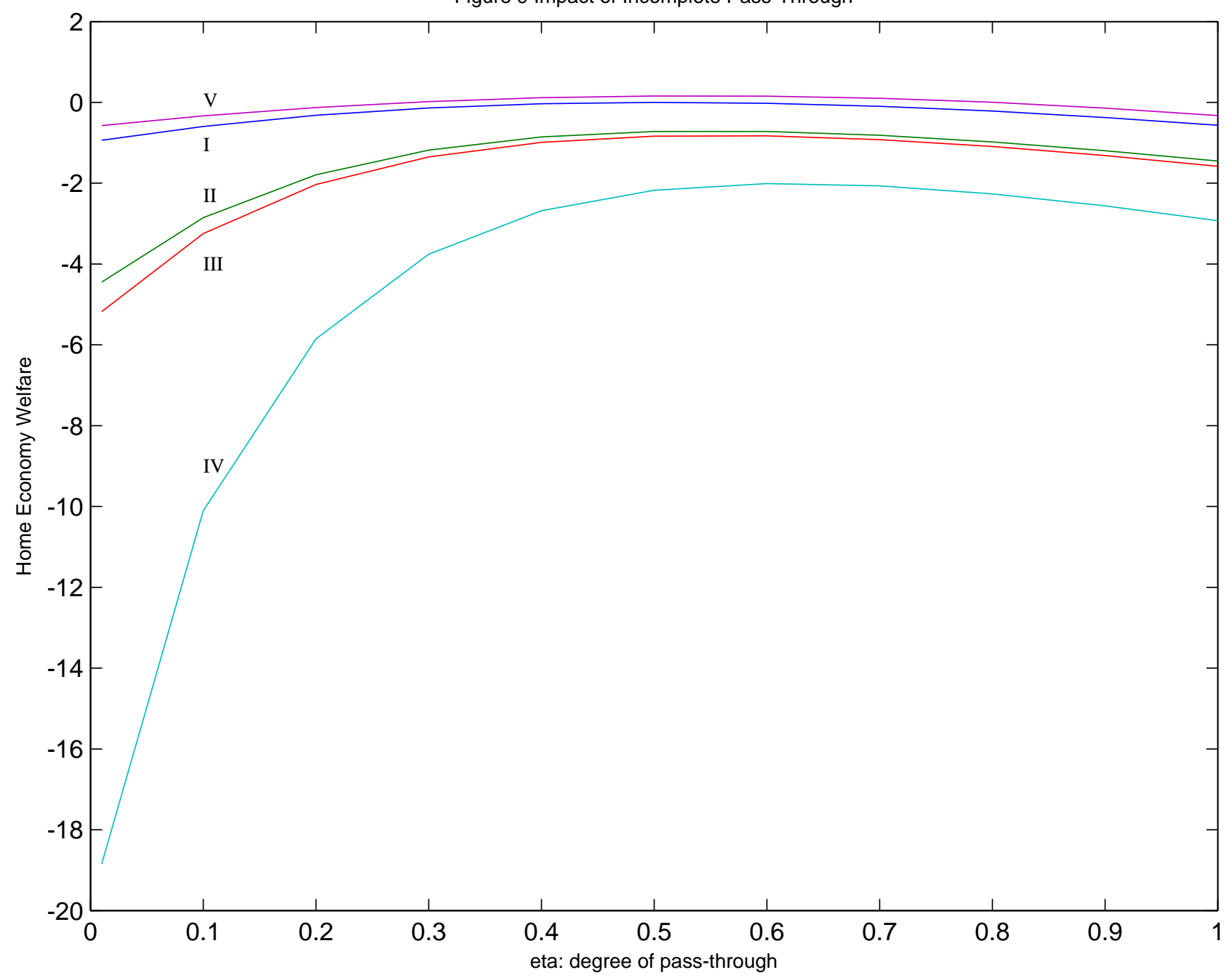


Table 4A

$v=0.5, n=0.5$

Home Welfare

Home Rule

\begin{tabular}{|c|c|c|c|c|c|}
\cline { 2 - 6 } \multicolumn{1}{c|}{} & I & II & III & IV & V \\
\hline Foreign Rule & & & & & \\
\hline I & -0.27228 & -0.84683 & -0.87378 & -1.33740 & -0.01316 \\
\hline II & -0.23622 & -0.81007 & -0.82960 & -1.28390 & 0.02951 \\
\hline III & -0.23614 & -0.81121 & -0.83145 & -1.28610 & 0.03076 \\
\hline IV & -0.19527 & -0.77141 & -0.78889 & -1.24020 & 0.07663 \\
\hline V & -0.27602 & -0.85182 & -0.88433 & -1.35840 & -0.02190 \\
\hline
\end{tabular}

Table 4B

$v=0.5, n=0.5$

Foreign Welfare

Home Rule

\begin{tabular}{|c|c|c|c|c|c|}
\cline { 2 - 6 } \multicolumn{1}{c|}{} & I & II & III & IV & V \\
\hline Foreign Rule & & & & & \\
\hline I & -0.29831 & -0.31357 & -0.31386 & -0.32017 & -0.29245 \\
\hline II & -0.92511 & -0.93155 & -0.93475 & -0.93819 & -0.92984 \\
\hline III & -0.95266 & -0.95350 & -0.95492 & -0.95762 & -0.96346 \\
\hline IV & -1.46580 & -1.45330 & -1.45700 & -1.45530 & -1.49290 \\
\hline V & -0.02949 & -0.04710 & -0.04673 & -0.05345 & -0.02012 \\
\hline
\end{tabular}

Table 5 Pay-offs for the Home and Foreign Country

(mixed shocks)

Table 5A

$v=1.0, n=0.5$

Home Welfare

Home Rule

\begin{tabular}{|c|c|c|c|c|c|}
\cline { 2 - 6 } \multicolumn{1}{c|}{} & I & II & III & IV & V \\
\hline Foreign Rule & & & & & \\
\hline I & -0.27268 & -0.81888 & -0.84946 & -1.30340 & -0.03230 \\
\hline II & -0.26971 & -0.81527 & -0.83846 & -1.28500 & -0.02534 \\
\hline III & -0.26916 & -0.81548 & -0.83909 & -1.28550 & -0.02364 \\
\hline IV & -0.24280 & -0.78955 & -0.81065 & -1.25420 & 0.00539 \\
\hline V & -0.25888 & -0.80371 & -0.83885 & -1.29810 & -0.02252 \\
\hline
\end{tabular}

Table 5B

$v=1.0, n=0.5$

Foreign Welfare

Home Rule

\begin{tabular}{|c|c|c|c|c|c|}
\cline { 2 - 6 } \multicolumn{1}{c|}{} & I & II & III & IV & V \\
\hline Foreign Rule & & & & & \\
\hline I & -0.29935 & -0.34590 & -0.34599 & -0.36357 & -0.27547 \\
\hline II & -0.89599 & -0.93415 & -0.93711 & -0.95090 & -0.87787 \\
\hline III & -0.92744 & -0.96044 & -0.96042 & -0.97411 & -0.91431 \\
\hline IV & -1.42750 & -1.44890 & -1.45110 & -1.46010 & -1.42380 \\
\hline V & -0.04879 & -0.09817 & -0.09754 & -0.11611 & -0.02184 \\
\hline
\end{tabular}


Table 6 Open Economy Rules

\begin{tabular}{|c|c|c|c|c|c|c|c|}
\hline Rule & $\mathrm{V}-1$ & $\mathrm{~V}-2$ & $\mathrm{~V}-3$ & $\mathrm{~V}-4$ & $\mathrm{~V}-5$ & $\mathrm{~V}-6$ & $\mathrm{~V}-7$ PPI \\
\hline Coefficient on: & & & & & & & \\
\hline Output & 0.06 & 0.06 & 0.06 & 0.06 & 0.06 & 0.06 & 0.06 \\
\hline Inflation-CPI & 1.2 & 1.2 & 1.2 & 1.2 & 1.2 & 1.2 & 0 \\
\hline Inflation-PPI & 0 & 0 & 0 & 0 & 0 & 0 & 1.2 \\
\hline Lagged i & 1.3 & 1.3 & 1.3 & 1.3 & 1.3 & 1.3 & 1.3 \\
\hline Exchange Rate & 0 & -0.1 & -0.2 & -0.3 & -0.4 & -0.5 & 0 \\
\hline Lagged Exchange Rate & 0 & 0.1 & 0.2 & 0.3 & 0.4 & 0.5 & 0 \\
\hline & & & & & & & \\
\hline Home Welfare & -0.1124 & -0.1016 & -0.0957 & -0.0976 & -0.1118 & -0.1454 & -0.3350 \\
\hline
\end{tabular}

